University of Nebraska - Lincoln

DigitalCommons@University of Nebraska - Lincoln

USDA National Wildlife Research Center - Staff Publications
U.S. Department of Agriculture: Animal and Plant Health Inspection Service

2017

\title{
Ecology and Management of Red-Winged Blackbirds
}

George M. Linz

USDA/APHIS/WS National Wildlife Research Center, george_m_linz@yahoo.com

Page E. Klug

USDA/APHIS/WS National Wildlife Research Center, pklug@usgs.gov

Richard A. Dolbeer

Wildlife Services

Follow this and additional works at: https://digitalcommons.unl.edu/icwdm_usdanwrc

Part of the Life Sciences Commons

Linz, George M.; Klug, Page E.; and Dolbeer, Richard A., "Ecology and Management of Red-Winged Blackbirds" (2017). USDA National Wildlife Research Center - Staff Publications. 1983.

https://digitalcommons.unl.edu/icwdm_usdanwrc/1983

This Article is brought to you for free and open access by the U.S. Department of Agriculture: Animal and Plant Health Inspection Service at DigitalCommons@University of Nebraska - Lincoln. It has been accepted for inclusion in USDA National Wildlife Research Center - Staff Publications by an authorized administrator of DigitalCommons@University of Nebraska - Lincoln. 


\section{Ecology and Management of Red-Winged Blackbirds}

\section{George M. Linz and Page E. Klug}

National Wildlife Research Center

Bismarck. North Dakota

\section{Richard A. Dolbeer}

Wildlife Services

Sandusky. Ohio

\section{CONTENTS}

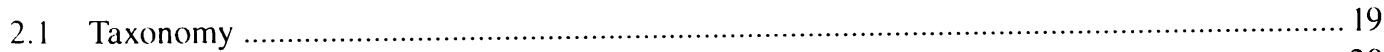

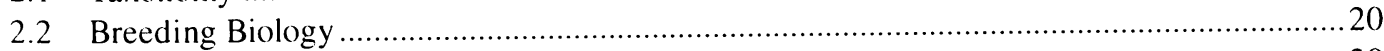

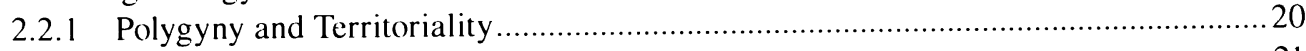

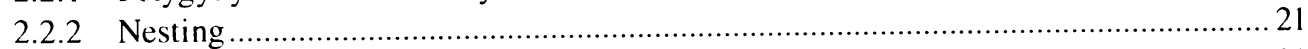

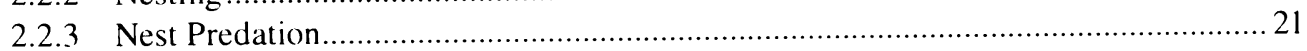

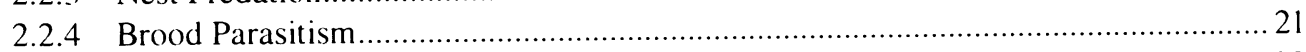

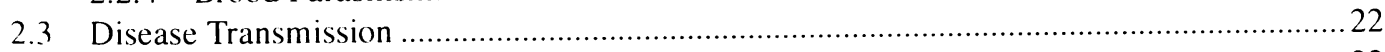

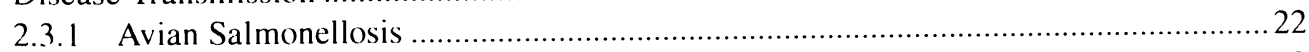



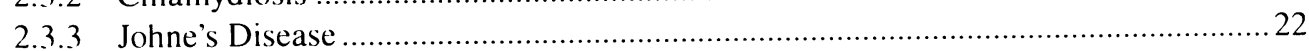

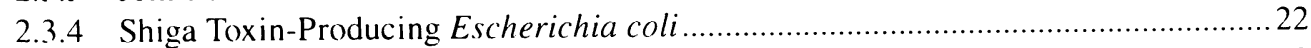

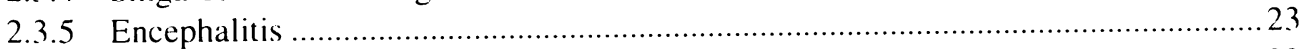

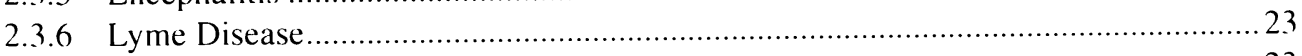

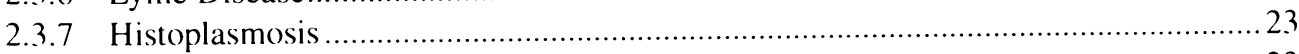

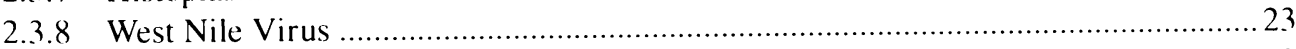

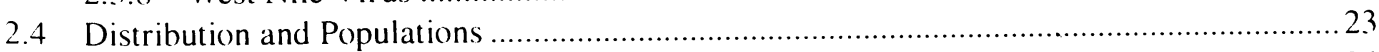

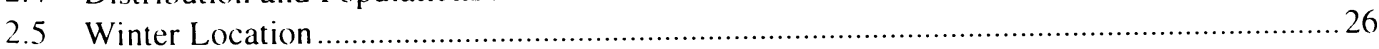

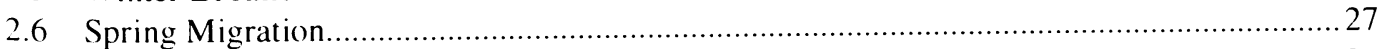

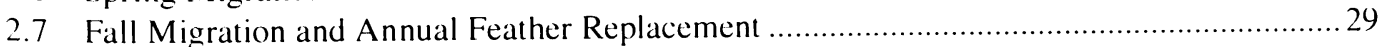

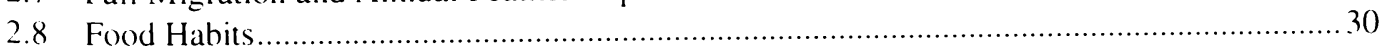

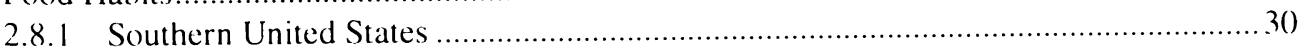

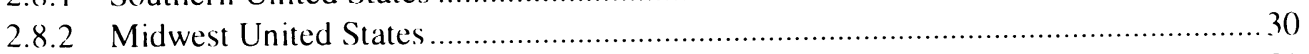

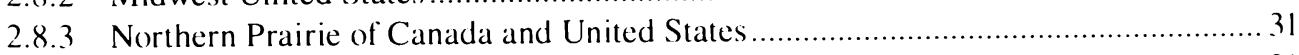

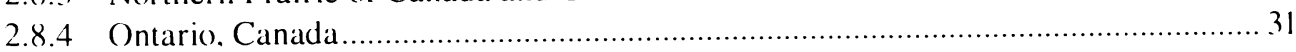

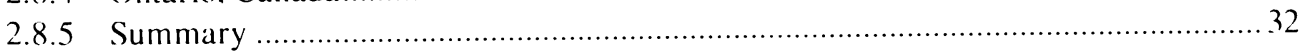




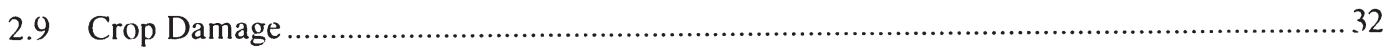

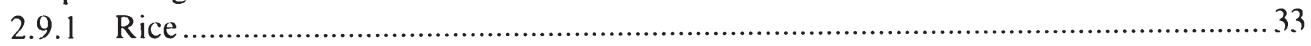

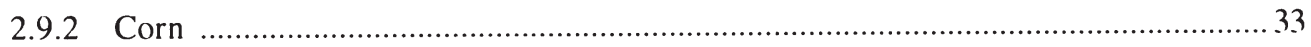

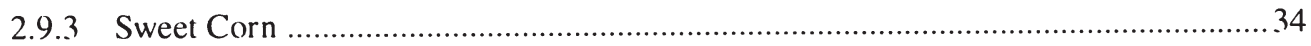

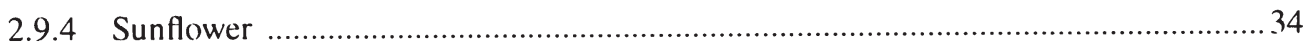

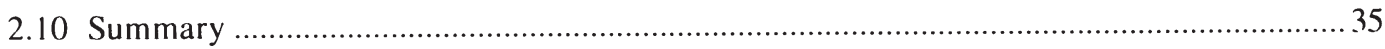

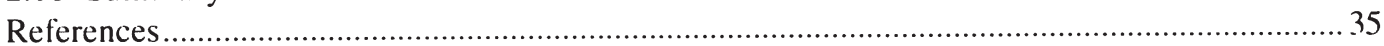

The red-winged blackbird (Agelaius phoeniceus) is one of the most abundant bird species in North America, with an estimated spring breeding population of 150 million individuals that nest in emergent wetland vegetation and upland habitats throughout the continent (Yasukawa and Searcy 1995; Forcey et al. 2015; Rosenberg et al. 2016). During the nonbreeding season, red-winged blackbirds are often found in flocks numbering from a few birds to many thousands, sometimes in association with other blackbird species and European starlings (Sturnus vulgaris). In winter, red-winged blackbirds and these associated species gather in roosts occasionally numbering over 10 million birds (Meanley and Royal 1976; White et al. 1985).

Migratory male red-winged blackbirds typically arrive at their nesting grounds in early March, a month before the females arrive. At this time, casual bird watchers are apt to notice the robinsized, male red-winged blackbirds with black feathers and highly conspicuous red and yellow epaulets (definitive plumage), prominently displayed while aggressively confronting intruders approaching their nesting territories (Figure 2.1). Loud singing (o-ka-leeee, konk-a-ree) by these males from high perches in their chosen territories adds to their aesthetic value. Second-year males returning to their natal area following their hatching year do not have the definitive plumage of adults. Rather, they have a duller black body and light red or orange epaulets (Yasukawa and Searcy 1995). The female, at least $20 \%$ smaller and far less noticeable with brownish feathers, is often misidentified as a large streaked sparrow (Figure 2.2) (Yasukawa and Searcy 1995; Jaramillo and Burke 1999).

Published in 1914, A.A. Allen's "The Red-Winged Blackbird: A Study in the Ecology of a Cat-Tail Marsh" was arguably the foundation for all subsequent descriptive and experimental

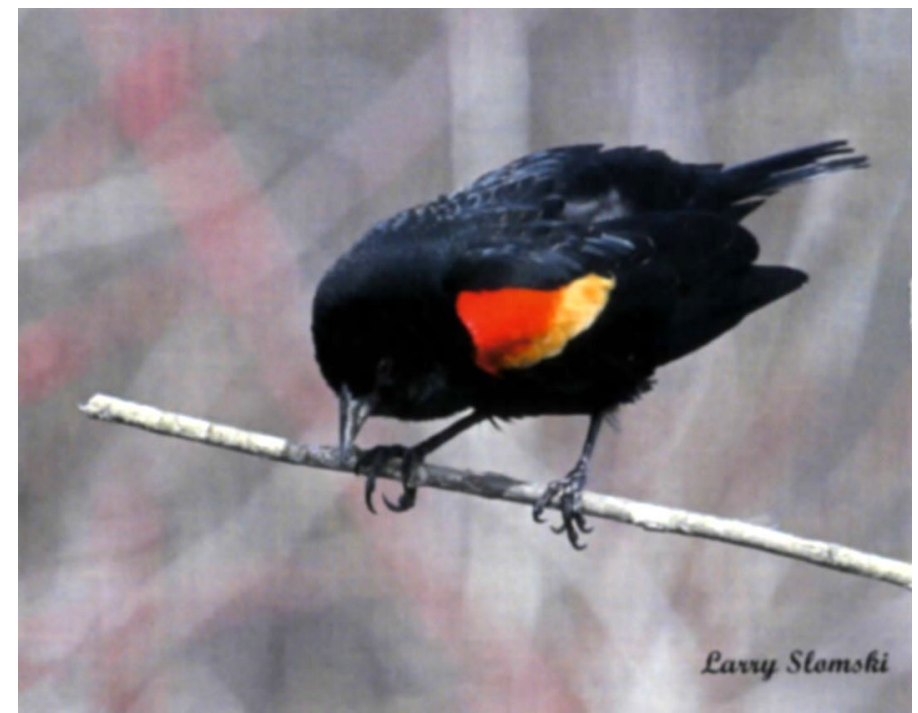

Figure 2.1 Male red-winged blackbird. (Courtesy of Larry Slomski.) 


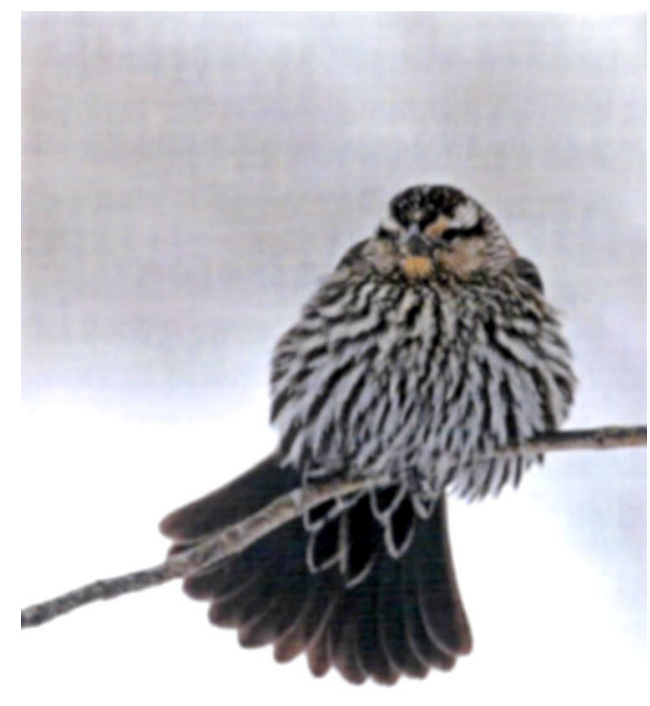

Ravry Slemski

Figure 2.2 Female red-winged blackbird. (Courtesy of Larry Slomski.)

studies on the biology and management of blackbirds (Icteridae). Red-winged blackbirds' abundance, polygamous breeding system, penchant for sprouting and ripening crops, and propensity to gather in large roosting congregations in the nonbreeding seasons have led scientists to pursue multiple avenues of research, resulting in over 1,000 publications found in peer-reviewed manuscripts, books, monographs, disquisitions, and scientific conference and workshop proceedings (Yasukawa and Searcy 1995). Books focused on the biology of red-winged blackbirds have captured data across many of these studies (Payne 1969; Nero 1984; Searcy and Yasukawa 1995; Yasukawa and Searcy 1995; Beletsky 1996; Beletsky and Orians 1996; Jaramillo and Burke 1999). Here, we highlight key findings of these studies; readers are urged to examine the cited publications for details.

\subsection{TAXONOMY}

The red-winged blackbird's Latin-derived scientific name A. phoeniceus is apt; Agelaius means "belonging to a flock" and phoeniceus means "deep red." The common name for the red-winged blackbird is taken from the black adult male's distinctive red epaulets, which are visible when the bird is flying or displaying.

Size differences between sexes are substantial, with males and females of the eastern red-winged blackbird (Agelaius phoeniceus phoeniceus) subspecies averaging about $68 \mathrm{~g}$ and $44 \mathrm{~g}$, respectively, based on birds captured in Ohio and Nebraska (Holcomb and Twiest 1968; Scharf et al. 2008). Individual mass can vary $15 \%-20 \%$ within a population. Additionally, premigratory fattening, often by feeding extensively on ripening crops, can increase body mass by $>10 \%$ (Linz 1982).

Based on morphological characteristics (e.g., wing and tail length, bill size, and shape), ornithologists suggest that there are perhaps 14 subspecies of red-winged blackbird scattered across North America. Yasukawa and Searcy (1995) encouraged further research using advanced molecular methods to clearly differentiate subspecies. 
Regardless of subspecies, males have about $20 \%$ longer wing, tail, culmen, and tarsus measurements than do females (Yasukawa and Searcy 1995). For example, the male eastern red-winged blackbird has an average wing length of $121 \mathrm{~mm}$ and culmen length of $24 \mathrm{~mm}$, compared to females with $98 \mathrm{~mm}$ and $19 \mathrm{~mm}$ wing and culmen lengths, respectively (Yasukawa and Searcy 1995).

\subsection{BREEDING BIOLOGY}

\subsubsection{Polygyny and Territoriality}

After arriving on the breeding grounds, after-second-year (ASY) male ( $\geq 2$ years old) red-winged blackbirds search for territories, where they defend exclusive areas in an attempt to attract one or more after-hatching year (AHY) females ( $\geq 1$ year old), with harems of two to five females common (Searcy and Yasukawa 1995; Beletsky 1996). In a study in upland habitat in Ohio, the ratio of nesting females to male territories remained quite stable in May and June, averaging about 1.9:1.0, but new females constantly moved into territories and nested, as previously established females finished nesting and departed (Dolbeer 1976). For the entire nesting season each year, an average of over 4.0 different females nested per territory. These data suggest that some social mechanism limited the number of nesting females at any one time to a "carrying capacity" of the territories. The total number of females nesting in the territories was maximized by a temporal spacing of nest attempts by different females. During this time of active nesting, males display vigorously from perches within their territory and sing frequently, especially in the morning and evening in response to male song and females encroaching on their territory.

Polygyny results in second-year (SY) and ASY males that do not establish a nesting territory and therefore are referred to as "floaters." ASY males are comparable in size and plumage to territory owners, and virtually all SY males are smaller and have a distinctly duller plumage than ASY males. SY males are sexually mature and physiologically capable of successful mating but rarely successfully defend a territory (Payne 1969). No differences in size, testosterone levels, or reproductive capability have been found between ASY floaters and territorial males (Shutler and Weatherhead 1991; Dufour and Weatherhead 1998), and there is no reason to believe that ASY floaters are incapable of contributing to extra-pair copulation (Moulton et al. 2013). The surplus population of floater males explores an area searching for an opportunity to claim a territory (Shutler and Weatherhead 1992; Yasukawa and Searcy 1995; Sawin et al. 2003a; Moulton et al. 2013). Although a few territories are gained by replacing existing males or inserting themselves between existing territories, the majority of males gain their territories from owners that have disappeared (Picman 1987). Chance probably plays a strong role in initial territory acquisition (Eckert and Weatherhead 1987). Regardless, vacant territories are quickly occupied, sometimes within minutes and commonly within 48 hours (Eckert and Weatherhead 1987; Shutler and Weatherhead 1992; Sawin et al. 2003a).

The annual survival rate of adult red-winged blackbirds ranges from $42 \%$ to $62 \%$, with a mean life expectancy of 2.14 years (Beletsky 1996). Based on an average annual mortality rate near $50 \%$, the floater pool should be larger than the population of territorial males. In Washington, Beletsky and Orians (1996) reported that about $56.6 \%$ and $26.5 \%$ of territorial males initially acquired a territory when they were two and three years old, respectively.

Experienced males typically return to the same territory or nearby habitat the following year. For example, Beletsky and Orians (1996) reported that $52 \%-65 \%$ of males holding a territory in one year also held a territory the next year, with $70 \%$ reclaiming their original territories or found in nearby habitat. Similarly, Dufour and Weatherhead (1998) found that $51 \%-60 \%$ of territorial males in Ontario returned to their original or adjacent territory. In British Columbia, Picman (1987) found that $94 \%$ of returning males reclaimed their original territories. In comparison, females exhibit weak mate fidelity but strong marsh fidelity and appear to use experience in settlement decisions (Dolbeer 1976; Beletsky and Orians 1991). 


\subsubsection{Nesting}

Emergent wetland vegetation is the preferred breeding habitat of red-winged blackbirds, but they also nest successfully in upland habitats, particularly hay fields, pasture, fallow fields, conservation reserve lands, and even shrubs (Dolbeer 1976; Beletsky 1996). In the Prairie Pothole Region (PPR) of the northern Great Plains, red-winged blackbirds are especially productive because there are about 404,000 ha of emergent wetland vegetation that provide ideal nest substrate through the breeding season (Ralston et al. 2007; Forcey et al. 2015).

Females provide the majority of parental investment; their responsibilities include nest building, incubation, nest defense, and provisioning of nestlings and fledglings. Females typically build a woven open cup nest in 1-3 days in vertical vegetation (Yasukawa and Searcy 1995; Beletsky 1996). Beginning 1-4 days after nest completion, one egg is laid daily, with a mean of three to four eggs, but nests with five eggs are not unusual (Yasukawa and Searcy 1995; Belesky 1996). Females incubate eggs and feed the nestlings from 11-13 and 10-12 days, respectively. Renesting after a nest failure may occur one to two times per season but varies depending on the length of the breeding season and stage of nesting when failure occurs.

In comparison, males limit their direct involvement to include only nest defense and limited provisioning (Searcy and Yasukawa 1995; Beletsky 1996). Regional differences may occur in the amount and quality of parental care provided by males within and among populations (Yasukawa et al. 1990; Linz et al. 2011a). In almost all cases where males feed nestlings, feeding is supplemental to female provisioning and occurs only after nestlings are four days old (Yasukawa et al. 1990). Male feeding has been shown to increase with an increase in brood size, nestling age, proportion of male nestlings, and male experience (Yasukawa et al. 1990; Patterson 1991). Overall, the number of offspring per territorial male has been shown to increase with breeding experience (Orians and Beletsky 1989; Beletsky and Orians 1991). Males with more breeding experience defend nests more intensely than their less experienced counterparts (Knight and Temple 1986; Yasukawa et al. 1987). Yasukawa et al. (1987) and Linz et al. (2014) reported that intensive nest defense did not result in higher nest success, whereas Weatherhead (1990) and Knight and Temple (1986) found that nests defended aggressively were more likely to be successful than nests defended with less vigor.

\subsubsection{Nest Predation}

Red-winged blackbird nests are frequently lost to a multitude of causes, including abandonment, predation, starvation, weather, brood parasitism, and failure of nest support vegetation (Beletsky 1996; Sawin et al. 2003b). Searcy and Yasukawa (1995) identified predation as the main source of nest failure. Red-winged blackbirds breeding in upland areas and at the edge of wetlands may experience more predation than those breeding in the interior, where deeper water limits access by mammalian predators (Picman et al. 1993). Beletsky (1996) collated data across 14 studies and found that $30 \%-50 \%$ of red-winged blackbird nests were depredated. Likewise, Searcy and Yasukawa (1995) reported that predation ranged from $27 \%$ to $50 \%$ in 10 studies, with nest predators including avian, mammalian, and reptilian predators. In the northern Great Plains, red-winged blackbirds are excluded from deeper water nesting sites by yellow-headed blackbirds (Xanthocephalus xanthocephalus) and thus might be exposed to more predation than counterparts in regions where yellow-headed blackbirds do not breed (Orians and Willson 1964; Twedt and Crawford 1995).

\subsubsection{Brood Parasitism}

Brood parasitism by brown-headed cowbirds (Molothrus ater) can negatively influence reproductive success in red-winged blackbirds (Searcy and Yasukawa 1995; Clotfelter and Yasukawa 1999; Lorenzana and Sealy 1999). For example, Lorenzana and Sealy (1999) found that brown-headed 
cowbird nestlings compete with host nestlings by consuming food otherwise meant for the host nestlings and can reduce red-winged blackbird productivity by up to 1.5 nestlings. Weatherhead (1989) concluded, however, that brown-headed cowbird parasitism did not reduce reproductive success in red-winged blackbirds, and Ortega and Cruz (1988) found conflicting results among study years. In the northern Great Plains, the populations of both red-winged blackbirds and brown-headed cowbirds are large, and thus nest success is probably affected more by yearly precipitation and predation than brood parasitism (Sawin et al. 2003b; Forcey et al. 2011, 2015; Rosenberg et al. 2016).

\subsection{DISEASE TRANSMISSION}

Red-winged blackbirds sometimes associate with European starlings ( $S$. vulgaris) and other blackbirds in concentrated animal feeding operations and can be found roosting together, often in numbers exceeding 1 million birds, in the nonbreeding season (Meanley and Royall 1976; Dolbeer et al. 1978). At least 65 different diseases transmittable to humans or domestic animals have been reported to occur in pigeons (Columbidae), European starlings, and house sparrows (Passer domesticus); a similar level of documentation is not available for red-winged blackbirds (Clark and McLean 2003). It is reasonable, however, that birds roosting and feeding together could share some of the same pathogens. The level of enhanced risk is unknown and warrants additional study before reasoned management options can be developed (Clark and McLean 2003). Here, we list and briefly discuss eight important diseases that have been associated with flocking blackbirds, including redwinged blackbirds. We refer the reader to Conover (2002) and Conover and Vail (2015) for a comprehensive review of diseases that can spread between birds and humans (zoonoses).

\subsubsection{Avian Salmonellosis}

Avian salmonellosis (primarily Salmonella spp.) has been documented in starlings and blackbirds species throughout the United States and is transmissible to humans, poultry, and livestock (Carlson et al. 2010, 2015; Conover and Vail 2015). Poultry production operators, however, have protected their buildings from free-ranging birds and thereby have greatly reduced the threat of an outbreak (Clark and McLean 2003).

\subsubsection{Chlamydiosis}

Chlamydiosis (also psittacosis, ornithosis, and parrot fever) is carried by starlings and blackbirds and can infect humans and domestic fowl, causing respiratory psittacosis and avian chlamydiosis, respectively. Infections result from inhaling Chlamydia psittaci that live in dried feces deposited by birds (Conover 2002; Conover and Vail 2015).

\subsubsection{Johne's Disease}

Johne's disease (Mycobacterium avium paratuberculosis) is a contagious, chronic, and sometimes fatal infection that can be carried by birds and primarily affects the small intestine of ruminants (Clark and McLean 2003; Corn et al. 2005). The bacteria are excreted in feces and milk and annually costs the U.S. dairy industry $\$ 200-\$ 250$ million in losses (Ott et al. 1999; Beard et al. 2001).

\subsubsection{Shiga Toxin-Producing Escherichia coli}

Shiga toxin-producing Escherichia coli (STEC) is another disease that might be transmitted by wild birds to cattle (Swirski et al. 2014; Conover and Vail 2015). In the cattle industry, average annual costs of illnesses related to STEC exceeded US\$267 million (National Cattleman's Beef 
Association 2004). Humans may get this disease from consuming tainted food products, especially ground beef. Further research is needed to better clarify the role of birds and other factors in the transmission or prevalence of this disease.

\subsubsection{Encephalitis}

St. Louis encephalitis and western equine encephalitis are zoonotic diseases found primarily in wild vertebrates but transmitted to humans by the bite of a mosquito. The viruses are carried by blackbirds and cause acute inflammation of the brain that leads to illness and sometimes death (Conover 2002; McLean and Ubico 2007; Conover and Vail 2015).

\subsubsection{Lyme Disease}

Lyme disease is caused by the bacterium Borreliela burgdorferi and is classified as a zoonosis because it is transmitted to humans through the bite of infected blacklegged ticks (Ixodes scapularis). Lyme disease can be transmitted by ticks that feed on birds (Conover and Vail 2015). Battaly and Fish (1993) established that the American robin (Turdus migratorius), common grackle (Quiscalus quiscula), and house wren (Troglodytes aedon) are hosts for immature ticks and thus are high risk species of concern for human health.

\subsubsection{Histoplasmosis}

Histoplasmosis (Histoplasma capsulatum) is a common and sometimes serious noncommunicable fungal disease that primarily affects the lungs (Conover 2002; Conover and Vail 2015). Humans can become ill with histoplasmosis by inhaling dust at roosts that have large accumulations of bird and bat excreta (Chu et al. 2006). Stickley and Weeks (1985) suggested that only those roosts occupied by birds for three or more years have been shown to be infested with $H$. capsulatum. Accordingly, birds roosting at a site the first winter might be allowed to remain, unless nuisance complaints dictate otherwise.

\subsubsection{West Nile Virus}

West Nile virus (WNV) is a disease that is life-threatening to humans and wildlife. Confirmed in North America in 1999, WNV rapidly spread across the United States along migratory routes, covering 12 states in one year (Lanciotti et al. 1999; Bernard et al. 2001). Bernard et al. (2001) reported that both red-winged blackbirds and common grackles tested positive for WNV. Sullivan et al. (2006) conducted a serological survey of WNV antibodies in central North Dakota and found the peak WNV antibody prevalence was 22\% in August of 2003 and 18\% in July of 2004. Their results suggest that migratory redwinged blackbird populations may be an important viral dispersal mechanism with the ability to spread arboviruses such as WNV across North America. Whether WNV or other diseases affects productivity or the speed and distance of a red-winged blackbird's movements and migration are not known.

\subsection{DISTRIBUTION AND POPULATIONS}

\section{SIDEBAR 2.1 THE NORTH AMERICAN BREEDING BIRD SURVEY}

In the 1960s, Chandler S. Robbins led the development of a long-term, large-scale avian survey program known as the North American Breeding Bird Survey (NABBS; Ziolkowski et al. 2010). The NABBS, which is jointly coordinated by the U.S. Geological Survey and the Canadian Wildlife Service, provides the best data available for national and regional population estimates and trend analyses on more than 420 bird species. Concerns about the effects of powerful 
pesticides (e.g., DDT) on bird populations provided the initial impetus for the survey, but habitat loss, changes in land use, contaminants, and climate change are also important threats to birds. The survey, which is conducted during the breeding season, covers most of the United States and Canada and consists of 4,100 routes $39.4 \mathrm{~km}$ long, with 3-minute stops at $0.8 \mathrm{~km}$ intervals. Skilled observers identify all birds seen and heard along the route. Researchers and statisticians analyze the data for each species and provide population estimates and trends (Sauer et al. 2017). Significant declines in a bird population might result in research to identify the cause and suggest management actions to stop or even reverse the decline (Stanton et al. 2016). The NABBS is often used in conjunction with National Land Cover Data Set and the National Climatic Data Center to model the effects of land use and climate variables on bird abundance (e.g., Forcey et al. 2011, 2015; Bateman et al. 2016).

In 1966, the North American Breeding Bird Survey (NABBS) was initiated to provide data for bird population estimates and trend analyses (Sidebar 2.1). Based on NABBS data, the Partners in Flight Science Committee estimated the breeding population of red-winged blackbirds at 150 million individuals in the United States and Canada (Rosenberg et al. 2016). Although it is one of the most widespread and numerous birds in North America (Figure 2.3), data from the NABBS indicate that the red-winged blackbird population has declined about $0.93 \%$ annually from 1966 to 2015 (Figure 2.4) (Sauer et al. 2017). On a continental basis, changing land-use patterns (e.g., wetland drainage, grassland conversion, urbanization) and perhaps climate change are likely to drive a sustained long-term bird population decline (Forcey et al. 2011, 2015). On a statewide basis, Blackwell and Dolbeer (2001) showed that changes in farm practices in Ohio, primarily a reduction in hayfield acreage and earlier spring mowing of hay, caused the red-winged blackbird

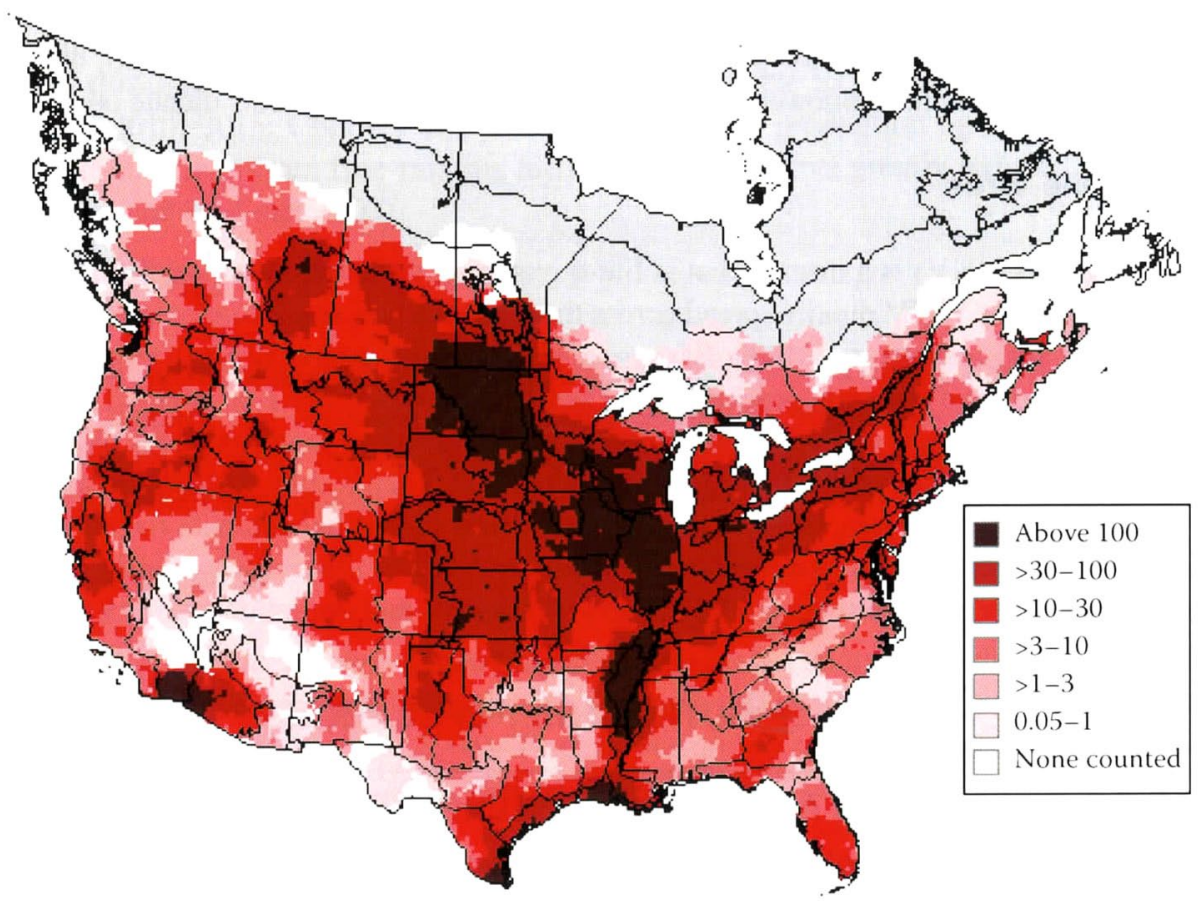

Figure 2.3 Relative abundance of red-winged blackbirds during nesting season (mean number of birds recorded per $39.4 \mathrm{~km}$ survey route) based on data from the North American Breeding Bird Survey, 2011-2015. (Sauer et al. 2017.) 


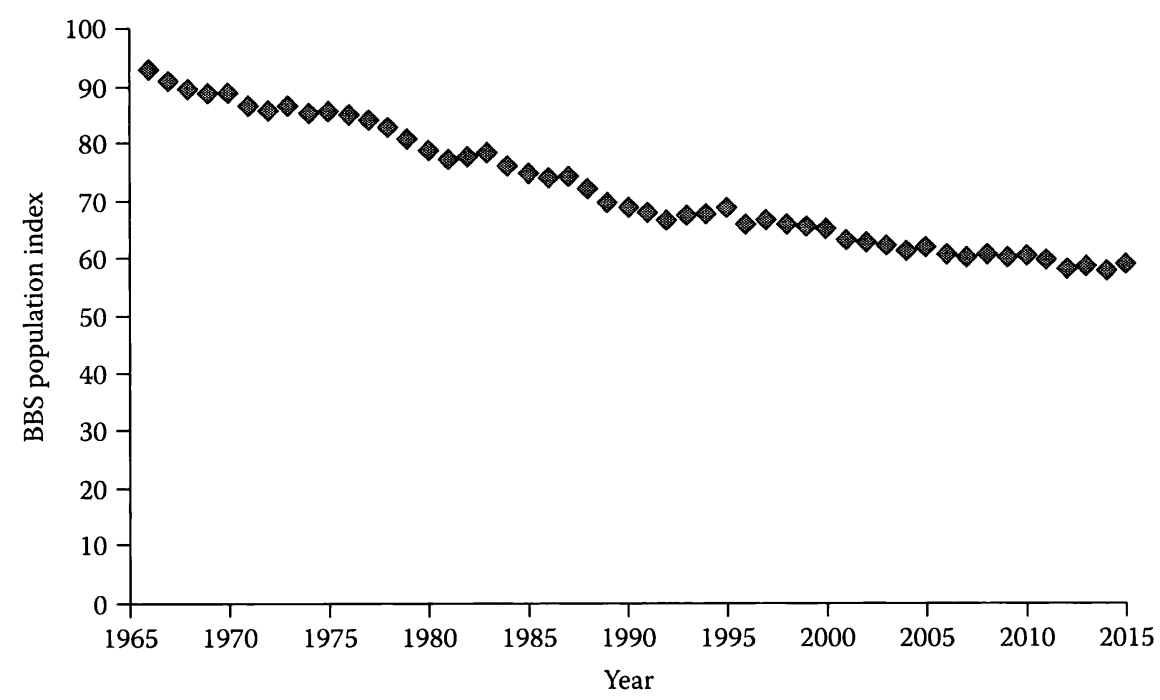

Figure 2.4 Population trend for red-winged blackbirds (mean number of birds recorded per $39.4 \mathrm{~km}$ survey route) based on data from the North American Breeding Bird Survey, 1966-2015. (Sauer et al. 2017.)

Table 2.1 Estimated Number of Breeding Pairs of Male Red-Winged Blackbirds Encountered during Surveys Conducted across Multiple Years in North Dakota

\begin{tabular}{lccl}
\hline Year & $\begin{array}{c}\text { Population Size } \\
(\times \mathbf{1 0 0 0})\end{array}$ & $\mathbf{9 5 \%} \mathbf{C l}$ & \multicolumn{1}{c}{ Source } \\
\hline 1967 & 2,129 & $1,745-2,439$ & Stewart and Kantrud 1972 \\
$1981-1982$ & 1,512 & $1,325-1,570$ & Besser 1985 \\
1990 & 1,143 & $792-1,494$ & Nelms et al. 1994 \\
1991 & 1,425 & $1,382-1,468$ & Nelms et al. 1999 \\
1992 & 1,306 & $1,021-1,591$ & Igl and Johnson 1997 \\
1993 & 1,536 & $1,224-1,848$ & Igl and Johnson 1997 \\
\hline
\end{tabular}

population to decline by 53\% between 1966 and 1996. This scenario is likely repeated throughout North America as agriculturalists make market-oriented decisions that affect land use.

Blackbird breeding populations in the northern Great Plains have received an inordinate amount of attention because their feeding on sunflower (Helianthus annuus) causes significant economic harm to growers (Linz et al. 2011b, 2015). In North Dakota, where $40 \%$ of U.S. sunflower is grown, both a roadside blackbird index and a general avian density survey were established in 1965 and 1967, respectively. From 1965 to 1981, Besser et al. (1984) conducted a roadside index survey in North Dakota and South Dakota and found that the red-winged blackbird population declined 30\% from the first three years (1965-1968) compared to the last three years of the survey (1979-1981). In 1967, Stewart and Kantrud (1972) established 130 plots of 64.75 ha each across North Dakota to estimate the density of all breeding birds. During the inaugural survey, they found two million pairs of red-winged blackbirds. The survey was repeated in 1981-1982 (Besser 1985), 1990 (Nelms et al. 1994), and 1992 and 1993 (Igl and Johnson 1997) (Table 2.1). 
In 1991, Nelms et al. (1999) conducted a comprehensive population density survey using a random selection of 10 plots of 64.75 ha within 80 townships $\left(93.2 \mathrm{~km}^{2}\right)$. They estimated that 1.4 million pairs of red-winged blackbirds were breeding in North Dakota. Overall, these data suggest that the red-winged blackbird population declined $>30 \%$ between 1967 and the early 1990s. Finally, from 1996 to 1998, Linz et al. (2002) repeated the Stewart and Kantrud (1972) survey on 67 plots located within the PPR and found that the population was $32 \%$ higher compared to the average numbers in 1967, 1981-82, and 1990. The years of higher population numbers were marked by above-average precipitation (U.S. Department of Agriculture 1999).

The fluctuation in North Dakota's red-winged blackbird population is likely related to wet-dry precipitation cycles in the state (Besser et al. 1984; Linz et al. 2002; Forcey et al. 2015). In dry years, agriculturalists are able to till the soil in shallow wetlands, destroying emergent vegetation used as nesting substrate. In the 2000s, historically high commodity prices and reduced funding for grassland conservation programs resulted in these lands being converted to grain crops, which resulted in reduced nesting opportunities for birds (Claassen and Hungerford 2014; USDA 2015b). The NABBS data show, however, that between 2003 and 2015 the red-winged blackbird population in the PPR has remained statistically unchanged (Sauer et al. 2017). Future bird surveys are warranted, given ongoing land-use changes due to urbanization, climate change, hydrocarbon extraction, and changes in grassland cover due to the potential increase in grassland acres for biofuels that might offset declining Conservation Reserve Program (CRP) enrollment (Johnson and lgl 1995; Murray and Best 2003; Weatherhead 2005).

\subsection{WINTER LOCATION}

From 1961 to 1966, DeGrazio et al. (1969) banded 27,000 blackbirds during late summer in eastern South Dakota and recovered red-winged blackbirds, yellow-headed blackbirds, and common grackles from December through February across the wintering range. Most red-winged blackbirds and common grackles were found to overwinter in eastern Texas and western Louisiana, whereas yellow-headed blackbirds were mainly found in central Mexico. Meanley (1964) banded 6,000 red-winged blackbirds in the Patuxent River marsh complex in Maryland and found that most of the banded birds wintered along the eastern coastal states. Mott (1984) reported the majority of blackbirds banded $(n=20,000)$ in Kentucky and Tennessee during the winter were recovered on nesting grounds in the northeastern United States, whereas $50 \%$ of the starlings were hatched in the subject states. In a comprehensive analysis of the continental movement and migration patterns of red-winged blackbirds, Dolbeer $(1978,1982)$ concluded that red-winged blackbirds in the eastern United States tend to winter in the southeastern United States, whereas birds from the northern plains winter in the south-central states of Texas and Louisiana. Adult birds usually returned to the same area to breed each year, but in winter roosts there was a high degree of intermingling of birds from northern areas. Female red-winged blackbirds from a given northern area typically migrated further south than did males (Dolbeer 1982).

During winter, red-winged blackbirds gather nightly in winter roosting congregations, often with other blackbirds and European starlings. The last comprehensive national survey of roosts, in the winter of 1974-1975, recorded 723 roosts containing an estimated 537 million blackbirds and starlings. Red-winged blackbirds comprised 38\% (204 million) of the total roosting population (Meanley and Royall 1976).

These large aggregations of blackbirds led to citizen concerns about health issues, crop damage, structural damage due to bird droppings, and safety related to bird-aircraft strikes. As a result, in 1977 the U.S. Fish and Wildlife Service established the Kentucky Field Station at Bowling Green, Kentucky, USA, to research these problems and to find potential management solutions. Scientists developed the use of a sprinkler-irrigation system for applying a wetting agent (PA-14 surfactant) to blackbirds and starlings roosting in trees. The applications of PA-14 caused hypothermia and as a result sometimes killed millions of birds (Heisterberg et al. 1987; Dolbeer et al. 1997). PA-14 is no longer registered 
for this use due to environmental concerns, and its replacement compound, sodium lauryl sulfate, is not commonly used to manage bird populations (Dolbeer et al. 1997; U.S. Department of Agriculture 2012). They also successfully developed the avicide compound DRC-1339 (a.i., 3-chloro-p-toluidine hydrochloride), a compound still in use for reducing starling numbers at feedlots and blackbirds damaging sprouting rice (e.g., Glahn and Wilson 1992; U.S. Department of Agriculture 2015).

\subsection{SPRING MIGRATION}

Dolbeer (1978) used band recoveries to conduct a comprehensive analysis of continental movement and migration patterns of red-winged blackbirds. He suggested that red-winged blackbird spring migration occurs from about February 21 to April 24 (pre-reproductive period) in most areas of the United States. Male red-winged blackbirds generally leave the wintering areas earlier than females and arrive in breeding areas to establish territories before females arrive (Yasukawa and Searcy 1995).

Migration from the southern United States begins in February and peaks in March. Wilson (1985) analyzed morphological data (larger birds presumed to be migrants) to conclude that $78 \%$ of the red-winged blackbirds in Louisiana during March were local breeding birds, suggesting that most of the damage to newly seeded and sprouting rice was caused by these birds. Using banding data, Bruggers and Dolbeer (1990) found that resident birds constituted 16 of 20 non-banding-station recoveries during spring planting in March and April. This further corroborated Wilson (1985), who suggested that local red-winged blackbirds were responsible for most crop damage during planting. Potential bias associated with collecting data at banding stations prompted Bruggers and Dolbeer (1990) to advocate mass-marking and additional banding to further refine the relationship of migration and rice damage in the Gulf Coast region. To that end, 7 million red-winged blackbirds were aerially tagged with a fluorescent particle marker in Louisiana in 1995 (Sidebar 2.2) (Cummings and Avery 2003). Birds collected the following spring on breeding grounds across North America showed that the marked birds in Louisiana roosts were scattered across 13 states and central Manitoba, Canada.

\section{SIDEBAR 2.2 FORMULATION AND APPLICATION OF AERIAL MASS COLOR-MARKING}

Aerial mass color-marking was used to track the local and regional movements of blackbirds using night roosts from 1982 to 2001 (Otis et al. 1986; Knittle et al. 1987; Linz et al. 1991; Homan et al. 2004). The formulation consisted of an acrylic adhesive, food-grade propylene glycol, water, fluorescent-pigmented resin, surfactant, and foam suppressor (Homan and Linz 2005). The formulation was applied to flocks of blackbirds with a fixed-wing aircraft from an altitude of 15-20 m. The pilot usually flew high over the wetland to flush waterfowl and wading birds. The sprays occurred during the 20-30-minute period of twilight following sunset. A 416-liter load was sufficient to mark 100,000 birds in 15 minutes. A coarse droplet size of approximately 400 microns was used because it leaves well-defined splash marks of color on the birds. The spray dries in 3-5 minutes and adheres particularly well to feather surfaces as the birds fly through the descending spray mist. Studies on marked, free-ranging red-winged blackbirds showed that $30 \%$ of the initial marks were lost 4-6 weeks after spraying (Knittle and Johns 1986). Resin particles lodged in the barbules, however, can remain much longer, often several months after the date of application (Homan et al. 2004). The marker formulation is nontoxic to freshwater fish and chironomid larvae (Bills and Knittle 1986; Knittle and Johns 1986). Color-marking was coordinated with the U.S. Geological Survey Bird Banding Laboratory. 
Crop damage in the northern Great Plains has prompted researchers to expend considerable effort to define the spring migration routes of red-winged blackbirds in the central United States, with the assumption that population management might be implemented at key stopover locations (Knittle et al. 1987; Homan et al. 2004). Attempts to reduce the red-winged blackbird population were not undertaken, but detailed information on their spring migratory timing and dispersal patterns was obtained (Blackwell et al. 2003; Homan et al. 2004; Linz et al. 2011b). Migration to breeding areas in the northern Great Plains occurs in April, when large migrating flocks can be found in northeastern South Dakota, until mid-April, when their numbers begin to decrease (Linz et al. 2003; Homan et al. 2004). In some years, flocks of female red-winged blackbirds can be found in northeastern South Dakota in early May (G. Linz, personal observation).

In 1982, 1983, and 1985, Knittle et al. $(1987,1996)$ used an aerially applied fluorescent pigment to mark millions of male red-winged blackbirds in northwestern Missouri, eastern South Dakota, and western Minnesota. Red-winged blackbirds using spring roosts in northwestern Missouri and southeastern South Dakota migrated northwest to breeding sites in or near sunflower-producing areas. Using these data and bird-banding data, Stehn (1989) proposed that blackbirds responsible for sunflower depredation originated from breeding territories located in a very large area including most of North Dakota (except the southwest corner), the eastern third of South Dakota, far western Minnesota, southern Manitoba, and southeastern Saskatchewan (Figure 2.5).

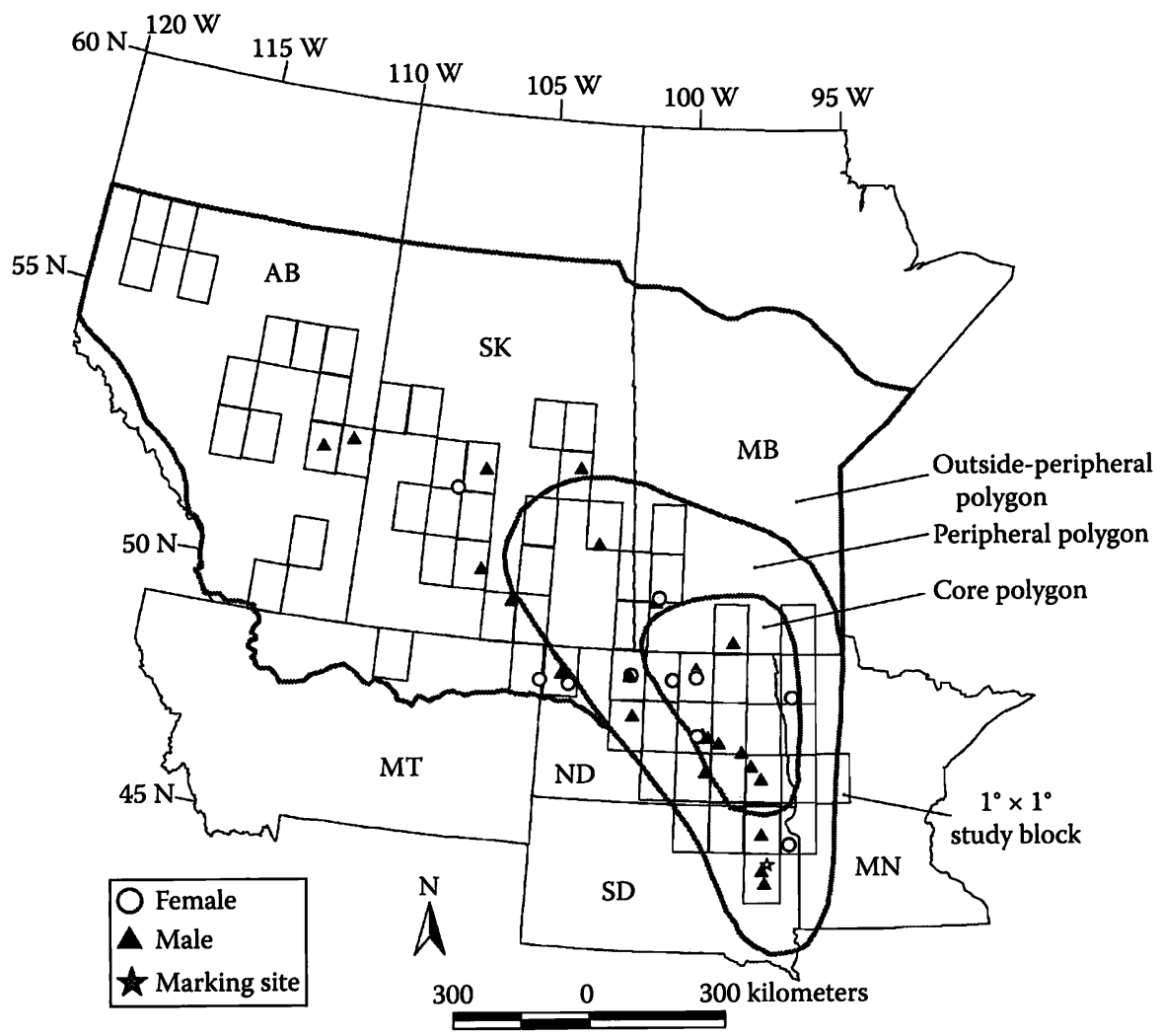

Figure 2.5 In April 2001, three blackbird roosts located in eastern South Dakota $\left(44^{\circ} 48^{\prime} \mathrm{N}, 9^{\circ} 21^{\prime} \mathrm{W}\right)$ were aerially marked with a fluorescent pigment. Breeding red-winged blackbirds were randomly collected in the United States and Canada, of which 33 were marked. The polygons were based on an analysis of banding and re-sighting data, physiography, and proximity to the area of concentrated sunflower production. (Homan et al. 2004.) 
Homan et al. (2004) refined our knowledge of migration patterns by marking red-winged blackbirds in eastern South Dakota and collecting both males and females in breeding territories. They determined that $82 \%$ of marked birds using staging areas in eastern South Dakota during spring migration were breeding in or near the core region of sunflower production in the PPR. Peer et al. (2003) used NABBS data and density estimates to determine that red-winged blackbird population sizes in this region were 27 million in the spring and 39 million post-reproduction. Using banding data, Dolbeer (1978) showed that in the United States local nesting red-winged blackbirds and their offspring stay within $200 \mathrm{~km}$ of their breeding area until feather molt and replacement is completed in early October. He found, however, that birds breeding in Alberta and Saskatchewan Canada moved an average of $729 \mathrm{~km}$, suggesting that they were moving south during feather molt (i.e., the process of losing feathers and replacing them).

\subsection{FALL MIGRATION AND ANNUAL FEATHER REPLACEMENT}

During the peak of annual feather molt, the ability of birds to fly efficiently is compromised and explains why blackbirds are difficult to frighten out of roosts and crop fields during late summer (Smith and Bird 1964). For example, Handegard (1988) reported that hazing blackbirds from sunflower fields with airplanes was particularly difficult during August and early September, which coincides with the peak of molt. Additionally, growing feathers requires extra energy and increases predation risk because of reduced flying capability (Rappole 2013). Thus, a thorough understanding of this critical period of the red-winged blackbird's life cycle is necessary in developing an integrated crop damage management plan.

Meanley and Bond (1970) recognized the importance of the red-winged blackbird's annual molt in relation to fall migration. They found that across Arkansas, Maryland, and Michigan, the majority of red-winged blackbirds initiated molt in late July to early August, with most of the birds completing molt by October 1 . At any stage of development, the red-winged blackbird usually had two, but sometimes three and rarely four, nonfunctional primary remiges (wing flight feathers). All feather tracts completed molt at approximately the same time. Further, Meanley and Bond (1970) concluded that most red-winged blackbirds complete feather molt before migrating.

Linz et al. (1983) studied the molt of red-winged blackbirds across five age-sex classes in a migratory population in Cass County, North Dakota. They found that SY males (generally nonbreeding) began molt earlier and were more synchronized than ASY males and AHY females. By the last week of July, the molt of the SY males had advanced one primary remige ahead of ASY males and AHY females. During the latter part of nesting season (July 22 through August 18), a larger percentage of the males $(\sim 95 \%)$ were molting than were the females $(80 \%-85 \%)$. The percentage of nonmolting females may have represented renesting birds and later-nesting SY females. Linz et al. (1983) suggested that differences in molt timing among and within each of the age-sex classes was probably related to the duration of nesting activities.

Red-winged blackbirds normally remain within $200 \mathrm{~km}$ of their breeding area until molt is complete (Dolbeer 1978). However, through an analysis of banding returns Dolbeer (1978) showed that birds nesting in western Canada may migrate during August and September. Molt would not be complete during the earlier part of this period. Linz et al. (1983) calculated that individual red-winged blackbirds complete molt in at least nine weeks. Therefore, the first birds should have completed molt by September 9 . However they did not collect a red-winged blackbird with complete winter plumage until the week of September 23. This suggested that many birds leave North Dakota upon completion of molt or just before the completion of molt and that birds less advanced in molt arrive from the north during the same period. 


\subsection{FOOD HABITS}

Crase and DeHaven (1975) published an annotated bibliography that lists 233 references on the food habits of blackbirds published from 1831 to 1974 . Since 1974, additional food habits studies have been conducted to help identify and quantify what species observed in the crop fields were eating. Food habits studies are labor intensive but are considered a necessary early step in defining a given damage issue. Data from these studies were used to develop economic models (Weatherhead et al. 1982; Peer et al. 2003) and provide insight into potential damage management strategies, especially for the development of alternative foraging sites (Hagy et al. 2008). Here, we review major red-winged blackbird food habits studies conducted in the southern and midwest regions of the United States, the northern prairie region of the United States and Canada, and Ontario, Canada.

\subsubsection{Southern United States}

Meanley (1961) analyzed the gizzard contents of 130 red-winged blackbirds collected in August and September 1959 in an uncultivated wild rice (Zizania aquatica) bed in a tidal marsh in Maryland. Wild rice is a 2-m tall plant that features many tillers and stems, which provide both roosting habitat and a food source for birds. Meanley (1961) found that weed seeds made up 58\% of their diet, followed by wild rice (24\%), ripening corn (12\%), and 5\% animal matter (mostly insects). Since Meanley's publication, production of cultivated wild rice has become an established industry in California, Minnesota, Oregon, and Wisconsin, while harvesting of uncultivated rice has continued in numerous northern states (Marcum and Gorenzel 1994; Hauan 2015). To our knowledge, a bird's food habits study related to cultivated wild rice has not been conducted.

Wilson (1985) conducted the most recent food habits study in the rice growing region of the southeastern United States. From October 1979 to August 1980 and August to September 1983, he collected 402 red-winged blackbirds in southwest Louisiana and found that cultivated white rice made up 37\% of the birds' annual diet, which was lower than the $54 \%$ and $45 \%$ reported previously by Kalmbach (1937) and Neff and Meanley (1957), respectively. During March and April, the primary planting months, red-winged blackbird diets averaged $24 \%$ white rice, $50 \%$ weed seeds, $18 \%$ red rice, and $6 \%$ insects. During July and August, when the rice crop was maturing, red-winged blackbird diets comprised $37 \%$ white rice, $52 \%$ weed seeds, $9 \%$ animal matter (mostly insects) and $2 \%$ red rice. Wilson (1985) suggested that this amount of rice in their diet was a minimum because rice in the milk and early dough stage of development is difficult to quantify.

\subsubsection{Midwest United States}

Stockdale (1959) analyzed the gizzard contents of 136 red-winged blackbirds collected from February 22 to November 15, 1959, in north-central Ohio. He divided the collections into five periods based on distinctly different activities. During the arrival period (February 22 to March 19) and mating and territory establishment period (March 20 to April 30), their diet was 96\% vegetable matter, with waste corn a major component. During the nesting period (May 1-31), the birds contained $74 \%$ and $26 \%$ vegetable and animal matter, respectively. From June 1 to July 15 (fledging period), their diets comprised $62 \%$ animal matter and $38 \%$ vegetable matter. Beetles (Scarabaeidae and Curculionidae) were commonly consumed in both the nesting and fledgling periods.

Throughout the flocking period (July 15 to November 15), which coincided with the availability of ripening corn, red-winged blackbirds ate $90 \%$ vegetable matter and $10 \%$ animal matter. Stockdale (1959) found corn in $76 \%$ of the birds during this time, with weed seeds and small grains found in $35 \%$ and $16 \%$ of the birds, respectively. Across the entire study period, vegetable food and animal matter made up $69 \%$ and $31 \%$ of their food consumption, respectively. 


\subsubsection{Northern Prairie of Canada and United States}

Bird and Smith (1964) analyzed the gullet and gizzard contents of 183 red-winged blackbirds collected from May to October 1960 in a diverse agriculture area in southern Manitoba, near the North Dakota border. During May, $66 \%$ and $26 \%$ of the birds' diets were made up of waste grains (sunflower, corn, small grains) and animal matter (largely insects), respectively.

During June and July (nesting season), $67 \%$ of their diets consisted of animal matter. From August to mid-October (harvest), red-winged blackbirds ate mostly vegetable matter (72\%), with ripening sunflower (38\%) dominating this portion of their diet. Animal matter made up $20 \%$ of their diet at this time.

Mott et al. (1972) analyzed the gizzard contents of 702 red-winged blackbirds collected from 1959 through 1965 during the spring, summer, and early fall in northeastern South Dakota. The highest use of oats (20\%) was between July 1 and August 15 and millet (16\%) was used most heavily from September 16 to 25. From August 16 to September 25, use of weed seeds and ripening corn peaked, comprising $39 \%$ and $25 \%$ of the red-winged blackbird diet, respectively. Overall, they reported that weed seeds $(23 \%)$, corn $(11 \%)$, oats $(10 \%)$, wheat $(7 \%)$, and millet $(3 \%)$ comprised the majority of their grain diet, whereas animal matter (mostly insects) contributed $25 \%$ of their diet. Finally, Mott et al. (1972) noted that males ate significantly more corn (29\%) than did females (9\%).

Linz et al. (1984) examined the esophageal contents of 1,182 red-winged blackbirds collected from late July to early November of 1979 and 1980 in sunflower and corn fields in southeastern North Dakota. At that time, this area was unique in North Dakota because agriculturalists regularly planted both field corn and sunflower in juxtaposition. Male diets in corn fields consisted of $45 \%$ corn and $41 \%$ weed seeds, whereas female diets contained $16 \%$ corn and $70 \%$ weed seeds. Males collected in sunflower fields contained $69 \%$ sunflower and $18 \%$ weed seeds, whereas females consumed $57 \%$ sunflower and $31 \%$ weed seeds. In both crops, males caused significantly more economic damage than did females.

\subsubsection{Ontario, Canada}

Hintz and Dyer (1970) analyzed the stomach contents of 650 red-winged blackbirds collected in southern Ontario to determine the daily rhythms and seasonal changes in diets. From July 20 to August 14, ripening wheat and oats comprised 58\% of the stomach contents and animal matter accounted for $36 \%$; from August 15 to September 10, corn constituted $81 \%$ of the stomach contents and animal matter accounted for $11 \%$. During both of these times, weed seeds made up the remainder of their diet. Overall, Hintz and Dyer (1970) found that red-winged blackbirds' caloric intake tended to be higher in the morning than afternoon and higher in the late summer than in the breeding season.

McNicol et al. (1982) collected 440 red-winged blackbirds from March to October 1977 and found that overall their diets were made up of $42 \%$ animal matter (mostly insects), followed by $31 \%$ corn, $18 \%$ weed seeds, and $6 \%$ oats. During the postbreeding and fall flocking period (July 11 to October 28 ), they found that male and female diets contained $56 \%$ and $28 \%$ corn, respectively. The remainder of their diets were largely made of weed seeds (males-24\%; females-44\%).

Finally, from August 15 to September 14, 1978, Gartshore et al. (1982) collected 143 red-winged blackbirds ( $72 \%$ males) from four corn fields that contained food in their esophagus and gullet. They analyzed the dry weight of foods for birds collected in three fields and found no difference in the amount of corn consumed by males and females, averaging $94 \%$. 


\subsubsection{Summary}

We note certain commonalities among the results of these food habits studies. Foremost, red-winged blackbird diets are flexible and food selection is dependent on availability. During the nesting season, red-winged blackbird diets consist of a high percentage of insects, whereas they feed insects to nestlings. The birds select insects because they are high in calories and protein and also plentiful in their nesting habitats. After nesting is complete, usually in July, red-winged blackbirds form small flocks and begin to exploit ripening cereal grains near wetland roosts. Their annual feather molt begins in earnest in late July and August, and they also initiate premigratory fattening. Red-winged blackbirds can meet their high calorie demand by exploiting the super-abundant food available in rice, corn, and sunflower fields. We note that as corn and sunflower crops mature and become more difficult to access and handling time increases, weed seeds found in crop fields and waste grain in harvested fields become important food sources, especially for females. Studies comparing the food habits of male and female red-winged blackbirds showed that females, which have smaller bodies and bills, cause less crop damage than do males (McNicol et al. 1982; Mott et al. 1972; Linz et al. 1984).

Transitioning from insects to crops is not complete, as food habits data show that red-winged blackbirds will also take harmful insects in crops (e.g., corn borers and seed weevils). Thus it is reasonable to suggest that red-winged blackbirds provide an ecological service by taking weed seeds and harmful insects that could benefit agriculture productivity (Bendell et al. 1981; McNicol et al. 1982; Bollinger and Caslick 1985; Dolbeer 1990; Okurut-Akol et al. 1990; Kirk et al. 1996). This service might be particularly important for organic growers who must avoid the use of chemical pesticides to maintain their certification for organic products. As a point of emphasis, this fast-growing segment of agriculture has increased from US\$3.4 billion in 1997 to US\$43.3 billion in 2015 (Hornick 2016). Regardless, it is prudent for agriculturalists and wildlife managers to consider the cost-benefits of blackbird management along with practicality, environmental safety, and wildlife stewardship (Dolbeer 1981; Slate et al. 1992; Blackwell et al. 2003; Linz et al. 2015).

\subsection{CROP DAMAGE}

For much of the year, red-winged blackbirds forage on insects, waste grain, and weed seeds (Stockdale 1959; White et al. 1985). During late winter, they might also be found feeding on high quality food found in concentrated animal feedlot operations (Dolbeer et al. 1978). However, red-winged blackbirds can sometimes cause significant economic damage to sprouting and ripening crops. Objective assessments of losses to birds is an arduous and expensive task but necessary to obtain scientifically defensible data for documenting economic losses, justifying the use of valuable resources, and assessing efficacy and cost-effectiveness of improved or new damage management techniques (Besser 1985). Shwiff and colleagues detail the economics of bird damage to crops in Chapter 12 of this volume. Here, we review studies that have sought to define the level of economic damage.

The red-winged blackbird prebreeding population (150 million) can sometimes cause significant damage to spring-seeded crops-especially rice but also corn and sunflower (Meanley 1971; Besser 1985; Wilson et al. 1989). Peer et al. (2003) calculated that the red-winged blackbird postbreeding population increases $45 \%$ in the northern Great Plains, which provides a reasonable national estimate of 217.5 million. These birds, along with other blackbird species, concentrate in wetland roosts containing up to several million birds. These birds forage in nearby ripening crops, especially field corn, rice, and sunflower, where they sometimes cause economically significant damage (Tyler and Kannenberg 1980; Weatherhead et al. 1982; Linz et al. 1984; Besser 1985; Wilson 1985; Dolbeer et al. 1986; Wilson et al. 1989; Peer et al. 2003). 
Blackbird damage is typically $1 \%-2 \%$ of the crop and most of that damage is within $8 \mathrm{~km}$ of a roost (Dolbeer 1981; Otis and Kilburn 1988; Wywialowski 1996; Dolbeer and Linz 2016). The uneven distribution of economic damage across producers, however, is the core of this wildlife management problem. That is, a small percentage of producers suffer the majority of the economic loss, which sometimes results in the abandonment of an otherwise profitable crop (Wywialowski 1996; Linz et al. 2011b; Linz and Hanzel 2015). Often blackbirds roost on public land or non-farmer-owned private land but forage on nearby crops. This leads to additional frustration by producers, who feel their hands are tied.

\subsubsection{Rice}

Rice is considered a minor crop in the United States, although about 1 million ha are planted annually (Cummings et al. 2005). Much of this crop is planted in the southeastern United States, which is also a favored wintering location for blackbirds (Meanley and Royall 1976). A substantial research effort began in the mid-1950s and intensified in the mid-1970s to expedite the development of damage management options (Meanley 1971). Researchers identified red-winged blackbirds as largely responsible for damaging sprouting and ripening rice, but brown-headed cowbirds, common grackles, and to a lesser extent boat-tailed grackles (Quiscalus major), great tailed grackles (Quiscalus mexicanus), and dickcissels (Spiza americana) have also been identified foraging in rice fields (Meanley 1971; Wilson 1985; Glahn and Wilson 1992; Avery et al. 2005).

Rice is readily available to foraging birds after seeding in the spring and while ripening prior to harvest in the fall. Bird damage to rice is not uniformly distributed but is localized and generally proportional to the size of nearby blackbird roosts (Avery et al. 2005). Both early-seeded and late-seeded fields are more likely to receive damage because both resident and spring-migrant blackbirds damage the sprouting rice, whereas resident and fall-migrant blackbirds damage ripening rice (Wilson et al. 1989). In some cases, locally severe blackbird damage to newly planted rice can result in a total loss and require that the crop be replanted (Wilson et al. 1989).

Reliable quantitative bird damage estimates are scarce due, in part, to difficult logistics associated with walking through ripening rice and newly planted, flooded fields. The most recent objective surveys were conducted in the 1980s. At that time, bird damage to newly planted rice cost growers in southwestern Louisiana and east Texas a combined total of about US $\$ 8$ million (Wilson et al. 1989; Decker et al. 1990). As an alternative to objective surveys, Cummings et al. (2005) surveyed rice growers in the United States and found that between 1996 and 2000 the average annual blackbird damage to newly planted rice ranged from $6 \%$ to $15 \%$ and the average percent loss to ripening rice ranged from $6 \%$ to $14 \%$. Louisiana and Arkansas respondents reported the highest damage.

\subsubsection{Corn}

Corn is a major crop in the United States, with about 14 million ha planted annually. In 1957, an intense research effort was initiated to alleviate blackbird damage to field corn in Ohio (Stockdale 1959). Scientists recognized that national damage was $<1 \%$ but local damage near roost sites could be economically significant, which was defined as over 5\% (Dolbeer 1980). Although red-winged blackbirds cause the greatest economic loss to ripening field corn, common grackles and yellow-headed blackbirds (in the central United States) also damage ripening corn (Dolbeer 1980; Twedt et al. 1991; Klosterman et al. 2013).

From 1977 to 1979, U.S. Fish and Wildlife Service personnel conducted a statewide survey in Ohio to quantify bird damage to field corn (Dolbeer 1980). The statewide estimates showed that primary damage (the actual corn removed by the birds) averaged $0.6 \%$, and secondary damage 
(molding or sprouting resulting from moisture entering the opened ear) averaged $0.1 \%$. Dolbeer (1980) reported that $<2.5 \%$ of cornfields in Ohio had losses $>5 \%$ and that all of these fields were within $8 \mathrm{~km}$ of a major wetland roost of blackbirds.

In 1981, Besser and Brady (1986) conducted an objective survey of bird damage to ripening field corn in 10 major producing states, representing $79 \%$ of the planted corn in the United States. The percentages of corn ears and fields with no damage were $98 \%$ and $84 \%$, respectively. In 1993, Wywialowski (1996) assessed wildlife damage to corn in the top ten corn-producing states and found that the average loss was $0.19 \%$, with damage 2.4 times higher on the edge of the fields versus the interior.

In North Dakota, corn planting increased threefold from 404,686 ha in the early 2000s to $1,416 \times 10^{3}$ ha in 2016 (U.S. Department of Agriculture 2016). Growers observed blackbirds in their fields and speculated that significant damage was occurring. Over a 2-year study, however, Klosterman et al. (2013) found that bird damage to cornfields in North Dakota averaged only $0.2 \%$ and no fields were found with over $5 \%$ damage.

Bird damage to field corn is likely ameliorated because corn is most vulnerable during the milk and dough development stages, a period of 3-4 weeks (Nielsen 2013). After that time, the corn kernel hardens, reducing its attractiveness to blackbirds, particularly females of both the red-winged blackbird and yellow-headed blackbird, which are both smaller than the males. Male blackbirds can damage field corn for several more weeks as the kernels mature and dry down to $<20 \%$ at harvest. Finally, bird feeding damage predisposes the ears to the development of various ear molds and rots, some of which may subsequently lead to the development of dangerous mycotoxins (Nielsen 2009).

\subsubsection{Sweet Corn}

Over the last decade, sweet corn was planted on an average of 98,000 ha in the United States (National Agricultural Statistics Service 2016). Systematic national surveys of blackbird damage to sweet corn have not been conducted. However, several countywide surveys conducted across four states in 1974 showed that damage ranged from $4.5 \%$ to $23.5 \%$ (Dolbeer et al. 1986). In 1965, surveys in Ontario showed sweet corn damage was $2.4 \%$ (range 0\%-13\%). Dolbeer (1990) pointed out that consumers find even a small amount of bird damage unsavory and will not purchase the corn. Damaged sweet corn delivered to canneries must be culled or trimmed, resulting in increased labor costs (Dolbeer 1990).

\subsubsection{Sunflower}

Sunflower is a minor crop in the United States, with 665,810 ha planted in 2016 (U.S. Department of Agriculture 2016). Blackbird (Icteridae) damage is the most common reason that sunflower producers in North Dakota stop planting sunflower (Linz et al. 2011b; Hulke and Kleingartner 2014). Ripening sunflower is particularly vulnerable to blackbirds because the crop is susceptible from early seed-set in mid-August until harvest in mid-October, a period of 8 weeks (Cummings et al. 1989; Linz et al. 2011b). In the 1970s, sunflower became an economically viable crop in the northern Great Plains but also presented a high-caloric food source for local nesting premigratory and migrating blackbirds. Beginning in 1979 and continuing to this day, scientists from the USDA APHIS Wildlife Services, National Wildlife Research Center, and North Dakota State University are collaborating on research designed to reduce blackbird damage to sunflower.

In 2009 and 2010, Klosterman et al. (2013) assessed bird damage to randomly selected sunflower fields in North Dakota's PPR and found that the average annual blackbird damage was $7.5 \times 10^{3}$ tons (2.7\%). Hothem et al. (1988) conducted a statewide (87\% of the samples in PPR), bird damage survey in 1979 and 1980 and found that blackbird damage averaged $27.6 \times 10^{3}$ tons $(1.8 \%)$. Thus, total tonnage lost was three times greater in the Hothem et al. (1988) survey than that reported 
by Klosterman et al. (2013). Assuming similar numbers of blackbirds were foraging in North Dakota across studies, the birds might have made up the difference in sunflower intake by seeking other food sources such as corn, small grains, waste grains, and weed seeds.

From 2002 to 2013 (except 2004), the National Sunflower Association sponsored comprehensive national surveys of blackbird damage in physiologically mature sunflower fields throughout the foremost sunflower growing states. Kandel and Linz (2016) analyzed and summarized the magnitude of blackbird damage in eight states from 2009 to 2013 and found that among biological production issues, blackbird damage to sunflower ranked third behind disease and weeds. Blackbird damage was substantial, with growers losing $2.6 \%$ and $1.7 \%$ per year of oilseed sunflower and confectionery production, respectively. Of the eight surveyed states, North Dakota ranked first in bird damage to confectionery and oilseed hybrids.

\subsection{SUMMARY}

Ubiquitous male red-winged blackbirds, with bright red epaulets framed by black feathers, are easily detected while perched and loudly singing (o-ka-leeee, konk-a-ree) on breeding territories, whereas females are more difficult to find because they are smaller and their feathers are cryptic brown with streaking. Most people in North America view "redwings" positively because of their splendor and as a harbinger of spring in northern areas. Their polygynous mating system combined with the conspicuous displays of males on territories and their propensity to conflict with human activities have made this species the subject of hundreds of scientific studies. Their large continental population is a testament to the success of this breeding system and ability to nest successfully in wide array of habitats. Their population is kept in check with a high annual mortality resulting from predation and weather events.

During much of their annual life cycle, they perform an important ecological service by eating waste grain, weed seeds, and insects and by serving as a prey base for many predatory birds and mammals. When grain crops begin to ripen, however, red-winged blackbirds exploit this superabundant food source, causing economic harm to growers. Moreover, nuisance, disease, and crop damage concerns arise in winter when they join with other blackbird species and European starlings in roosts throughout the southern United States. Since the 1950s, a substantial research effort has led to a better understanding of the ecology of red-winged blackbirds in relation to crop damage and the development of management methods designed to reduce the conflict between red-winged blackbirds and people. These management methods will be discussed in following chapters.

\section{REFERENCES}

Allen, A. A. 1914. The red-winged blackbird: A study in the ecology of a cattail marsh. Linnaean Society of New York 24-25:43-128.

Avery, M. L., S. J. Werner, J. L. Cummings, J. S. Humphrey, M. P. Milleson, J. C. Carlson, T. M. Primus, et al. 2005. Caffeine for reducing bird damage to newly seeded rice. Crop Protection 24:651-657.

Bateman, B. L., A. M. Pidgeon, V. C. Radeloff, J. VanDerWal, W. E. Thogmartin, S. J. Vavrus, and P. J. Heglund. 2016. The pace of past climate change vs. potential bird distributions and land use in the United States. Global Change Biology 22:1130-1144.

Battaly, G. R., and D. Fish. 1993. Relative importance of bird species as hosts for immature Ixodes dammini (Acari: Ixodidae) in a suburban residential landscape of southern New York state. Journal of Medical Entomology 30:740-747.

Beard, P. M., M. J. Daniels, D. Henderson, A. Pirie, K. Rudge, D. Buxton, S. Rhind, et al. 2001. Paratuberculosis infection of nonruminant wildlife in Scotland. Journal of Clinical Microbiology 39:1517-1521.

Beletsky, L. D. 1996. The red-winged blackbird: The biology of a strongly polygynous songbird. Academic Press, San Diego, CA. 
Beletsky, L. D., and G. H. Orians. 1991. Effects of breeding experience and familiarity on site fidelity in female red-winged blackbirds. Ecology 72:787-796.

Beletsky, L. D., and G. H. Orians. 1996. Red-winged blackbirds: Decision making and reproductive success. University of Chicago Press, Chicago, IL.

Bendell, B. E., P. J. Weatherhead, and R. K. Stewart. 1981. The impact of predation by red-winged blackbirds on European corn borer populations. Canadian Journal of Zoology 59:1535-1538.

Bernard, K. A., J. G. Maffei, S. A. Jones, E. B. Kauffman, G. Ebel, A. P. Dupuis, 2nd, K. A. Ngo, et al. 2001. West Nile virus infection in birds and mosquitoes, New York State, 2000. Emerging Infectious Diseases 7:679-685.

Besser, J. F. 1985. Changes in breeding blackbird numbers in North Dakota from 1967 to 1981-82. Prairie Naturalist 17:133-142.

Besser, J. F., and D. J. Brady. 1986. Bird damage to ripening field corn increases in the United States from 1971 to 1981. U.S. Fish and Wildlife Service, Fish and Wildlife Leaflet 7, Washington, DC.

Besser, J. F., J. W. DeGrazio, J. L. Guarino, D. F. Mott, D. L. Otis, B. R. Besser, and C. E. Knittle. 1984. Decline in breeding red-winged blackbirds in the Dakotas, 1965-1981. Journal of Field Ornithology 55:435-443.

Bills, T. D., and C. E. Knittle. 1986. Toxicity of DayGlo ${ }^{\circledR}$ fluorescent pigment material to four species of fish. Bird Damage Research Report 359. U.S. Fish and Wildlife Service, Denver Wildlife Research Center, Denver, CO.

Bird, R. D., and L. B. Smith. 1964. The food habits of the red-winged blackbird, Agelaius phoeniceus, in Manitoba. Canadian Field-Naturalist 78:179-186.

Blackwell, B. F., and R. A. Dolbeer. 2001. Decline of the red-winged blackbird population in Ohio correlated to changes in agriculture (1965-1996). Journal of Wildlife Management 65:661-667.

Blackwell, B. F., E. Huszar, G. M. Linz, and R. A. Dolbeer. 2003. Lethal control of red-winged blackbirds to manage damage to sunflower: An economic evaluation. Journal of Wildlife Management 67:818-828.

Bollinger, E. K., and J. W. Caslick. 1985. Red-winged blackbird predation on northern corn rootworm beetles in field corn. Journal of Applied Ecology 22:39-48.

Brugger, K. E., and R. A. Dolbeer. 1990. Geographic origin of red-winged blackbirds relative to rice culture in southwestern and southcentral Louisiana. Journal of Field Ornithology 61:90-97.

Carlson, J. C., A. B. Franklin, D. R. Hyatt, S. E. Pettit, and G. M. Linz. 2010. The role of starlings in the spread of Salmonella within concentrated animal feeding operations. Journal of Applied Ecology 2:479-486.

Carlson, J. C., D. R. Hyatt, J. W. Ellis, D. R. Pipkin, A. M. Mangan, M. Russell, D. S. Bolte, et al. 2015. Mechanisms of antimicrobial resistant Salmonella enterica transmission associated with starlinglivestock interactions. Veterinary Microbiology 179:60-68.

Chu, J. H., C. Feudtner, K. Heydon, T. J. Walsh, and T. E. Zaoutis. 2006. Hospitalizations for endemic mycoses: A population-based national study. Clinical Infection Diseases 42:822-825.

Claassen, R., and A. Hungerford. 2014. 2014 Farm act continues most previous trends in conservation. U.S. Department of Agriculture, Economic Research Service, Washington, DC. http://www.ers.usda. gov/agricultural-act-of-2014-highlights-and-implications/conservation.aspx (accessed June 23, 2016).

Clark, L., and R. G. McLean. 2003. A review of pathogens of agricultural and human health interests found in blackbirds. In Management of North American Blackbirds: Special Symposium of the Wildlife Society Ninth Annual Conference, ed. G. M. Linz, pp. 103-108. National Wildlife Research Center, Fort Collins, CO.

Clotfelter, E. D., and K. Yasukawa. 1999. Impact of brood parasitism by brown-headed cowbirds on red-winged blackbird reproductive success. Condor 101:105-114.

Conover, M. R. 2002. Resolving human-wildlife conflicts: The science of wildlife damage management. CRC Press/Taylor \& Francis, Boca Raton, FL.

Conover, M. R., and R. M. Vail. 2015. Human diseases from wildlife. CRC Press/Taylor \& Francis, Boca Raton, FL.

Corn, J. L., E. J. B. Manning, S. Sreevatsan, and J. R. Fischer. 2005. Isolation of Mycobacterium avium subspecies paratuberculosis from free-ranging birds and mammals on livestock premises. Applied and Environmental Microbiology 71:6963-6967.

Crase, F. T., and R. W. DeHaven. 1975. Selected bibliography on the food habits of North American blackbirds. Special Scientific Report Wildlife 192. U.S. Department of Interior, U.S. Fish and Wildlife Service, Washington, DC. 
Cummings, J. L., and M. L. Avery. 2003. An overview of current blackbird research in the southern rice growing region of the United States. Wildlife Damage Management Conference 10:237-243.

Cummings, J. L., J. L. Guarino, and C. E. Knittle. 1989. Chronology of blackbird damage to sunflowers. Wildlife Society Bulletin 17:50-52.

Cummings, J., S. Shwiff, and S. Tupper. 2005. Economic impacts of blackbird damage to the rice industry. Wildlife Damage Management Conference 11:317-322.

Decker, D. G., M. L. Avery, and M. O. Way. 1990. Reducing blackbird damage to newly planted rice with a nontoxic clay-based seed coating. Vertebrate Pest Conference 14:327-331.

DeGrazio, J. W., J. F. Besser, and J. L. Guarino. 1969. Winter distribution of as related to corn damage control in Brown County, South Dakota. North America Wildlife Conference 34:131-136.

Dolbeer, R. A. 1976. Reproductive rate and temporal spacing of nesting of red-winged blackbirds in upland habitat. Auk 93:343-355.

Dolbeer, R. A. 1978. Movement and migration patterns of red-winged blackbirds: A continental overview. Bird-Banding 49:17-34.

Dolbeer, R. A. 1980. Blackbirds and corn in Ohio. U.S. Department of the Interior Fish and Wildlife Service Resource Publication 136, Washington, DC.

Dolbeer, R. A. 1981. Cost-benefit determination of blackbird damage control for cornfields. Wildlife Society Bulletin 9:44-51.

Dolbeer, R. A. 1982. Migration patterns for sex and age classes of blackbirds and starlings. Journal of Field Ornithology 53:28-46.

Dolbeer, R. A. 1990. Ornithology and integrated pest management: Red-winged blackbirds Agelaius phoeniceus and corn. Ibis 132:309-322.

Dolbeer, R. A., and G. M. Linz. 2016. Blackbirds. Wildlife Damage Management Technical Series, U.S. Department of Agriculture, Animal \& Plant Health Inspection Service, Wildlife Services, Washington, DC.

Dolbeer, R. A., D. F. Mott, and J. L. Belant. 1997. Blackbirds and starlings killed at winter roosts from PA-14 applications, 1974-1992: Implication for regional population management. Eastern Wildlife Damage Control Conference 7:77-86.

Dolbeer, R. A., P. P. Woronecki, and R. A. Stehn. 1986. Resistance of sweet corn to damage by blackbirds and starlings. Journal of the American Society for Horticultural Science 111:306-311.

Dolbeer, R. A., P. P. Woronecki, A. R. Stickley, Jr., and S. B. White. 1978. Agricultural impact of a winter population of blackbirds and starlings. Wilson Journal of Ornithology 90:31-44.

Dufour, K. W., and P. J. Weatherhead. 1998. Reproductive consequences of bilateral asymmetry for individual male red-winged blackbird. Behavioral Ecology 9:232-242.

Eckert, C. G., and P. J. Weatherhead. 1987. Competition for territories in red-winged blackbirds: Is resourceholding potential realized? Behavioral Ecology and Sociobiology 20:369-375.

Forcey, G. M., W. E. Thogmartin, G. M. Linz, W. J. Bleier, and P. C. McKann. 2011. Land use and climate influences on waterbirds in the Prairie Potholes. Journal of Biogeography 38:1694-1707.

Forcey, G. M., W. E. Thogmartin, G. M. Linz, P. C. McKann, and S. M. Crimmins. 2015. Spatially explicit modeling of blackbird abundance in the Prairie Pothole Region. Journal of Wildlife Management 79:1022-1033.

Gartshore, R. G., R. T. Brooks, J. D. Sommers, and F. F. Gilbert. 1982. Feeding ecology of the red-winged blackbird in field corn in Ontario. Journal of Wildlife Management 46:438-452.

Glahn, J. F., and E. A. Wilson. 1992. Effectiveness of DRC-1339 baiting for reducing blackbird damage to sprouting rice. Eastern Wildlife Damage Control Conference 5:117-123.

Hagy, H. M., G. M. Linz, and W. J. Bleier. 2008. Optimizing the use of decoy plots for blackbird control in commercial sunflower. Crop Protection 27:1442-1447.

Handegard, L. L. 1988. Using aircraft to control blackbird/sunflower depredations. Vertebrate Pest Conference 13:293-294.

Hauan, H. 2015. Zizania aquatica L., Wild Rice; An evaluation of cultivation, domestication, and production for use in the United States. University of Minnesota Digital Conservancy, Minneapolis, MN.

Heisterberg, J. F, A. R. Stickley, K. M. Garner, and P. D. Foster, Jr. 1987. Controlling blackbirds and starlings at winter roosts using PA-14. Eastern Wildlife Control Conference 3:177-183.

Hintz, J. V., and M. I. Dyer. 1970. Daily rhythm and season change in the summer diet of adult red-winged blackbirds. Journal of Wildlife Management 34:789-799. 
Holcomb, L. C., and G. Twiest. 1968. Red-winged blackbird nestling growth compared to adult size and differential development of structures. Ohio Journal of Science 68:277-284.

Homan, H. J., and G. M. Linz. 2005. Aerial mass color- marking of blackbird roosts. Northern Great Plains Workshop. South Dakota State University, Brookings, SD.

Homan, H. J., G. M. Linz, R. M. Engeman, and L. B. Penry. 2004. Spring dispersal patterns of red-winged blackbirds, Agelaius phoeniceus, staging in eastern South Dakota. Canadian Field-Naturalist 118:201-209.

Hornick, M. 2016. Organic sales reach milestones. The Packer/Farm Journal Media, Lenexa, KS. http://www. thepacker.com/news/organic-sales-reach-milestones (accessed July 20, 2016).

Hothem, R. L., R. W. DeHaven, and S. D. Fairaizl. 1988. Bird damage to sunflower in North Dakota, South Dakota, and Minnesota, 1979-1981. Fish and Wildlife Technical Report 15, U.S. Fish and Wildlife Service, Washington, DC.

Hulke, B. S., and L. W. Kleingartner. 2014. Sunflower. In Yield gains in major U.S. field crops, eds. S. Smith, B. Diers, J. Specht, and B. Carver, pp. 433-457. Soil Science Society of America Special Publication 33. American Society of Agronomy, Crop Science Society of America, and Soil Science Society of America, Madison, WI.

Igl, L. D., and D. H. Johnson. 1997. Changes in breeding bird populations in North Dakota: 1967 to 1992-93. Auk 114:74-92.

Jaramillo, A., and P. Burke. 1999. New world blackbirds: The Icterids. Princeton University Press, Princeton, NJ.

Johnson, D. H., and L. D. Igl. 1995. Contributions of the conservation reserve program to populations of breeding birds in North Dakota. Wilson Bulletin 107:709-718.

Kalmbach, E. R. 1937. Blackbirds of the Gulf Coast in relation to the rice crop with notes on their food habits and life history. U.S. Bureau of Sport Fisheries and Wildlife, Denver Wildlife Research Center, Denver, CO.

Kandel, H., and G. M. Linz. 2016. Bird damage is an important economic agronomic factor influencing sunflower production. Wildlife Damage Management Conference 16:75-82.

Kirk, D. A., M. D. Evenden, and P. Mineau. 1996. Past and current attempts to evaluate the role of birds as predators of insect pests in temperate agriculture. In Current Ornithology. Vol 13, eds. V. Nolan, Jr. and E. D. Ketterson, pp. 175-269. Plenum Press, New York.

Klosterman, M. E., G. M. Linz, A. A. Slowik, and H. J. Homan. 2013. Comparisons between blackbird damage to corn and sunflower in North Dakota. Crop Protection 53:1-5.

Knight, R. L., and S. A. Temple. 1986. Why does intensity of avian defense increase during the nesting cycle? Auk 103:318-327.

Knittle, C. E., and B. E. Johns. 1986. Field-spray comparison of two particle-marker formulations used to mass-mark red-winged blackbirds. Bird Damage Research Report 371. U.S. Fish and Wildlife Service Denver Wildlife Research Center, Denver, CO.

Knittle, C. E., G. M. Linz, B. E. Johns, J. L. Cummings, J. E. Davis, Jr., and M. M. Jaeger. 1987. Dispersal of male red-winged blackbirds from two spring roosts in central North America. Journal of Field Ornithology 58:490-498.

Lanciotti, R. S., J. T. Roehrig, V. Deubel, J. Smith, M. Parker, K. Steele, B. Crise, et al. 1999. Origin of the West Nile virus responsible for an outbreak of encephalitis in the northeastern United States. Science 286:2333-2337.

Lorenzana, J. C., and S. G. Sealy. 1999. A meta-analysis of the impact of parasitism by the brown-headed cowbird on its host. Studies in Avian Biology 18:241-253.

Linz, G. M. 1982. Molt, food habits, and brown-headed cowbird parasitism of red-winged blackbirds in Cass County, North Dakota. PhD Dissertation. North Dakota State University, Fargo, ND.

Linz, G. M., S. B. Bolin, and J. F. Cassel. 1983. Postnuptial and postjuvenal molts of red-winged blackbirds in Cass County, North Dakota. Auk 100:206-209.

Linz, G. M., E. H. Bucher, S. B. Canavelli, E. Rodriguez, and M. L. Avery. 2015. Limitations of population suppression for protecting crops from bird depredation: A review. Crop Protection 76:46-52.

Linz, G. M., and J. J. Hanzel. 2015. Sunflower and bird pests. In Sunflower: Chemistry, production, processing, and utilization, eds. E. M. Force, N. T. Dunford, and J. J. Salas, pp. 175-186. AOCS Press, Urbana, IL.

Linz, G. M., H. J. Homan, S. W. Werner, H. M. Hagy, and W. J. Bleier. 201 lb. Assessment of bird management strategies to protect sunflower. BioScience 61:960-970.

Linz, G. M., C. E. Knittle, J. L. Cummings, J. E. Davis, Jr., D. L. Otis, and D. L. Bergman. 1991. Using aerial marking for assessing population dynamics of late summer roosting red-winged blackbirds. Prairie Naturalist 23:117-126. 
Linz, G. M., G. A. Knutsen, H. J. Homan, and W. J. Bleier. 2003. Baiting blackbirds (Icteridae) in stubble grain fields during spring migration in South Dakota. Crop Protection 22:261-264.

Linz, G. M., B. D. Peer, H. J. Homan, R. L. Wimberly, D.L. Bergman, and W. J. Bleier. 2002. Has an integrated pest management approach reduced blackbird damage to sunflower? In Human conflicts with wildlife: Economic considerations: Third NWRC Special Symposium, eds. L. Clark, J. Hone, J. A. Shivik, R. A. Watkins, K. C. Vercauteren, and J. K. Yoder, pp. 132-137. National Wildlife Research Center, Fort Collins, CO.

Linz, G. M., R. S. Sawin, and M. W. Lutman. 2014. The influence of breeding experience on nest success in red-winged blackbird. Western North American Naturalist 74:123-129.

Linz, G. M., R. S. Sawin, M. W. Lutman, and W. J. Bleier. 201 la. Modeling parental provisioning by red-winged blackbirds in North Dakota. Prairie Naturalist 43:92-99.

Linz, G. M., D. L. Vakoch, J. F. Cassel, and R. B. Carlson. 1984. Food of red-winged blackbirds (Agelaius phoeniceus) in sunflower fields and corn fields. Canadian Field-Naturalist 98:38-44.

Marcum, D. B., and W. P. Gorenzel. 1994. Grower practices for blackbird control in wild rice in California. Vertebrate Pest Conference 16:243-249.

McLean, R. G., and S. R. Ubico. 2007. Arboviruses in birds. In Infectious diseases of wild birds, eds. N. J. Thomas, D. B. Hunter, and C. T. Atkinson, pp. 17-62. Blackwell/Wiley, Hoboken, NJ.

McNicol, D. K., R. J. Robertson, and P. J. Weatherhead. 1982. Seasonal, habitat, and sex-specific food habits of red-winged blackbirds: Implications for agriculture. Canadian Journal of Zoology 60:3282-3289.

Meanley, B. 1961. Late-summer food of red-winged blackbirds in a fresh tidal-river marsh. Wilson Bulletin 73:36-40.

Meanley, B. 1964. Origin, structure, molt, and dispersal of a late summer red-winged blackbird population. Bird-Banding 35:32-38.

Meanley, B. 1971. Blackbirds and the southern rice crop. U.S. Department of Interior, U.S. Fish and Wildlife Service, Resource Publication 100. http://pubs.usgs.gov/rp/100/report.pdf (accessed June 28, 2016).

Meanley, B., and G. M. Bond. 1970. Molts and plumages of the red-winged blackbird with particular reference to fall migration. Bird-Banding 41:22-27.

Meanley, B., and C. W. Royall, Jr. 1976. The 1974-75 winter roost survey for blackbird and starlings. Bird Control Seminar 7:39-40.

Mott, D. F. 1984. Research on winter roosting blackbirds and starlings in the southeastern United States. Vertebrate Pest Conference 11:183-187.

Mott, D. F., R. R. West, J. W. DeGrazio, and J. L. Guarino. 1972. Foods of the red-winged blackbird in Brown County, South Dakota. Journal of Wildlife Management 36:983-987.

Moulton, L. L., G. M. Linz, and W. J. Bleier. 2013. Responses of territorial and floater male red-winged blackbirds to models of receptive females. Journal of Field Ornithology 84:160-170.

Murray, L. D., and L. B. Best. 2003. Short-term bird response to harvesting switchgrass for biomass in Iowa. Journal of Wildlife Management 67:611-621.

National Cattleman's Beef Association. 2004. A basic look at E. coli 0157. National Cattlemen's Beef Association, Centennial, CO.

Neff, J. A., and B. Meanley. 1957. Blackbirds and the Arkansas rice crop, Bulletin 584. Agricultural Experiment Station, University of Arkansas, Fayetteville, AR.

Nelms, C. O., W. J. Bleier, D. L. Otis, and G. M. Linz. 1994. Population estimates of breeding blackbirds in North Dakota, 1967, 1981-82, and 1990. American Midland Naturalist 132:256-263.

Nelms, C. O., D. L. Otis, G. M. Linz, and W. J. Bleier. 1999. Cluster sampling to estimate breeding blackbird populations in North Dakota. Wildlife Society Bulletin 27:931-937.

Nero, R. W. 1984. Redwings. Smithsonian Institution Press, Washington, DC.

Nielsen, (B.) R. L. 2009. Corn ear damage caused by bird feeding. Pest and Crop Newsletter. Purdue Cooperative Extension Service, Purdue University, Purdue. https://extension.entm.purdue.edu/ pestcrop/2009/issue24 (accessed February 5, 2016).

Nielsen, R. L. 2013. Grain fill stages in corn. Corny News Network, Purdue University, West Lafayette, IN. https://www.agry.purdue.edu/ext/corn/news/timeless/grainfill.html (accessed June 23, 2016).

Okurut-Akol, F. H., R. A. Dolbeer, and P. P. Woronecki. 1990. Red-winged blackbird and starling feeding responses on corn earworm-infested corn. Vertebrate Pest Conference 14:296-301.

Orians, G. H., and L. D. Beletsky. 1989. Red-winged blackbird. In Lifetime reproduction in birds, ed. I. Newton, pp. 183-197. Academic Press, New York. 
Orians, G. H., and M. F. Willson. 1964. Interspecific territories of birds. Ecology 45:736-745.

Ortega, C. P., and A. Cruz. 1988. Mechanisms of egg acceptance by marsh-dwelling blackbirds. Condor 90:349-358.

Otis, D. L., and C. M. Kilburn. 1988. Influence of environmental factors on blackbird damage to sunflower. U. S. Fish and Wildlife Service, Fish and Wildlife Technical Report 16. Washington, DC.

Otis, D. L., C. E. Knittle, and G. M. Linz. 1986. A method for estimating turnover in spring blackbird roosts. Journal of Wildlife Management 50:567-571.

Ott, S. L., S. J. Wells, and B. A. Wagner. 1999. Herd-level economic losses associated with Johne's disease on U.S. dairy operations. Preventive Veterinary Medicine 40:179-192.

Ralston, S. T., G. M. Linz, W. J. Bleier, and H. J. Homan. 2007. Cattail distribution and abundance in North Dakota. Journal of Aquatic Plant Management 45:21-24.

Rappole, J. H. 2013. The avian migrant: The biology of bird migration. Columbia University Press, New York. Rosenberg, K. V., J. A. Kennedy, R. Dettmers, P. J. Blancher, G.S. Butcher, W.C. Hunter, D. Mehlman, et al. 2016. Partners in Flight Landbird Conservation Plan: 2016 Revision for Canada and Continental United States. Partners in Flight Science Committee. http://www.partnersinflight.org/ (accessed September 25, 2016).

Patterson, C. B. 1991. Relative parental investment in the red-winged blackbird. Journal of Field Ornithology 62:1-18.

Payne, R. B. 1969. Breeding seasons and reproductive physiology of tricolored blackbirds and red-winged blackbirds. Publications in Zoology 90. University of California Press, Oakland, CA.

Peer, B. D., H. J. Homan, G. M. Linz, and W. J. Bleier. 2003. Impact of blackbird damage to sunflower: Bioenergetic and economic models. Ecological Applications 13:248-256.

Picman, J. 1987. Territory establishment, size, and tenacity by male red-winged blackbirds. Auk 104:405-412.

Picman, J., M. L. Milks, and M. Leptich. 1993. Patterns of predation on passerine nests in marshes: Effects of water depth and distance from edge. Auk 110:89-94.

Sauer, J. R., D. K. Niven, J. E. Hines, D. J. Ziolkowski, Jr, K. L. Pardieck, J. E. Fallon, and W. A. Link. 2017. The North American Breeding Bird Survey, results and analysis 1966-2015. Version 2.07.2017 USGS Patuxent Wildlife Research Center, Laurel, MD. https://www.mbr-pwrc.usgs.gov/bbs/bbs.html (accessed April 30, 2017).

Sawin, R. S., G. M. Linz, R. L. Wimberly, M. W. Lutman, and W. J. Bleier. 2003a. Estimating the number of nonbreeding male red-winged blackbirds in central North Dakota. In Management of North American Blackbirds: Special Symposium of the Wildlife Society Ninth Annual Conference, ed. G. M. Linz, pp. 97-102. National Wildlife Research Center, Fort Collins, CO.

Sawin, R. S., M. W. Lutman, G. M. Linz, and W. J. Bleier. 2003b. Predators on red-winged blackbird nests in eastern North Dakota. Journal of Field Ornithology 74:288-292.

Scharf, W. C., J. Kren, P. A. Johnsgard, and L. R. Brown. 2008. Body weights and species distribution of birds in Nebraska's Central and Western Platte Valley. Papers in Ornithology. http://digitalcommons.unl.edu/ biosciornithology/43/ (accessed June 16, 2016).

Searcy, W. A., and K. Yasukawa. 1995. Polygyny and sexual selection in red-winged blackbirds. Princeton University Press, Princeton, NJ.

Shutler, D., and P. J. Weatherhead. 1991. Owner and floater red-winged blackbirds: determinants of status. Behavioral Ecology and Sociobiology 28:235-241.

Shutler, D., and P. J. Weatherhead. 1992. Surplus territory contenders in male red-winged blackbirds: Where are the desperados? Behavioral Ecology and Sociobiology 31:97-106.

Slate, D., R. Owens, G. Connolly, and G. Simmons. 1992. Decision making for wildlife damage management. North American Wildlife Natural Resources Conference 57:52-62.

Smith, L. B., and R. D. Bird. 1964. Autumn flocking habits of the red-winged blackbird in southern Manitoba. Canadian Field-Naturalist 83:40-47.

Stanton, J. C., B. X. Semmens, P. C. McKann, T. Will, and W. E. Thogmartin. 2016. Flexible risk metrics for identifying and monitoring conservation-priority species. Ecological Indicators 61:683-692.

Stehn, R. A. 1989. Population ecology and management strategies for red-winged blackbirds. Bird Section Research Report No. 432. U.S. Fish and Wildlife Service, Denver Wildlife Research Center, Denver, CO.

Stewart, R. E., and H. A. Kantrud. 1972. Population estimates of breeding birds in North Dakota. Auk 89:766-788. 
Stickley, A. R., Jr., and R. J. Weeks. 1985. Histoplasmosis and its impact on blackbird/starling roost management. Eastern Wildlife Damage Control Conference 2:163-171.

Stockdale, T. M. 1959. Food habits and related activities of red-winged blackbirds (Agelaius phoeniceus) of north central Ohio. MS Thesis. The Ohio State University, Columbus, $\mathrm{OH}$.

Sullivan, H., G. M. Linz, L. Clark, and M. Salman. 2006. West Nile virus antibody prevalence in red-winged blackbirds (Agelaius phoeniceus) from North Dakota (2003-2004). Vector-Borne Zoonotic Disease 6:305-309.

Swirski, A. L., D. L. Pearl, M. L. Williams, H. J. Homan, G. M. Linz, and N. Cernicchiaro. 2014. Spatial epidemiology of Escherichia coli $\mathrm{O} 157: \mathrm{H} 7$ in dairy cattle in relation to night roosts of Sturnus vulgaris (European starling) in Ohio, USA (2007-2009). Zoonoses and Public Health 61:427-435.

Twedt, D. J., W. J. Bleier, and G. M. Linz. 1991. Geographic and temporal variation in the diet of yellowheaded blackbirds. Condor 93:975-986.

Twedt, D. J., and R. D. Crawford. 1995. Yellow-headed Blackbird (Xanthocephalus xanthocephalus). No. 192. In The Birds of North America, ed. A. Poole. Cornell Laboratory of Ornithology, Ithaca, NY.

Tyler, B. M. J., and L. W. Kannenberg. 1980. Blackbird damage to ripening field corn in Ontario. Canadian Journal of Zoology 58:469-472.

U.S. Department of Agriculture. 1999. North Dakota agricultural statistics 1999. North Dakota Agricultural Statistical Service, Fargo, ND.

U.S. Department of Agriculture. 2012. Sodium lauryl sulfate: European starling and blackbird wetting agent. Wildlife Services Tech Note. https://www.aphis.usda.gov/publications/wildlife_damage/content/printable_ version/WS_tech_note_sodium.pdf (accessed July 29, 2016).

U.S. Department of Agriculture. 2015. Environmental Assessment: Managing blackbird damage to sprouting rice in southwestern Louisiana. U.S. Department of Agriculture Wildlife Services, Washington, DC. https://www.aphis.usda.gov/regulations/pdfs/nepa/LA-Blackbird\%20EA\%20FINAL.pdf (accessed June 16, 2016).

U.S. Department of Agriculture. 2016. Quick Stats 2.0. U.S. Department of Agriculture, National Agricultural Statistics Service, Washington, DC. https://quickstats.nass.usda.gov/ (accessed September 25, 2016).

Weatherhead, P. J. 1989. Sex ratios, host-specific reproductive success, and impact of brown-headed cowbirds. Auk 106:358-366.

Weatherhead, P. J. 1990. Nest defense as sharable parental care in red-winged blackbird. Animal Behaviour 39:1173-1178.

Weatherhead, P. J. 2005. Effects of climate variation on timing of nesting, reproductive success, and offspring sex ratios of red-winged blackbirds. Oecologia 144:168-175.

Weatherhead, P. J., S. Tinker, and H. Greenwood. 1982. Indirect assessment of avian damage to agriculture. Journal of Applied Ecology 19:773-782.

White, S. B., R. A. Dolbeer, and T. A. Bookhout. 1985. Ecology, bioenergetics, and agricultural impacts of a winter-roosting population of blackbirds and starlings. Wildlife Monographs 93:1-42.

Wilson, E. A. 1985. Blackbird depredation on rice in southwestern Louisiana. MS Thesis. Louisiana State University, Baton Rouge, LA.

Wilson, E. A., E. A. LeBoeuf, K. M. Weaver, and D. J. LeBlanc. 1989. Delayed seeding for reducing blackbird damage to sprouting rice in southwestern Louisiana. Wildlife Society Bulletin 17:165-171.

Wywialowski, A. P. 1996. Field corn lost to wildlife in 1993. Wildlife Society Bulletin 24:264-271.

Yasukawa, K., R. L. Knight, and S. K. Skagen. 1987. Is courtship intensity a signal of male parental care in red-winged blackbird (Agelaius phoeniceus)? Auk 104:628-634.

Yasukawa, K., J. L. McClure, R. A. Boley, and J. Zanocco. 1990. Provisioning of nestlings by male and female red-winged blackbirds, Agelaius phoeniceus. Animal Behavior 40:153-166.

Yasukawa, K., and W. A. Searcy. 1995. Red-winged blackbird (Agelaius phoeniceus). No. 184. In The Birds of North America, ed. P. G. Rodewald. Cornell Lab of Ornithology, Ithaca, NY. https://birdsna.org/ Species-Account/bna/species/rewbla (accessed September 25, 2016).

Ziolkowski, D., Jr., K. Pardieck, and J. R. Sauer. 2010. On the road again for a bird survey that counts. Birding 42:32-40. 